\title{
Viral membrane fusion proteins and RNA sorting mechanisms for the molecular delivery by exosomes
}

\author{
I. Zubarev ${ }^{1,2^{2}}$, D. Vladimirtsev ${ }^{2}$, M. Vorontsova ${ }^{1,6}$, I. Blatov $^{2}$, K. Shevchenko ${ }^{3,4}$, S. Zvereva $^{2}$, E. Lunev ${ }^{5}$, E. \\ Faizuloev $^{7}$, N. Barlev ${ }^{2,3,8^{*}}$ \\ 1 Faculty of Medicine, Lomonosov Moscow State University, Moscow, Russia \\ 2 Laboratory of Intracellular Signaling, Moscow Institute of Physics and Technology, Dolgoprudny, Moscow \\ Region, Russian Federation \\ 3 Institute of Cytology RAS, St. Petersburg, Russia \\ 4 Chumakov Federal Scientific Center for Research and Development of Immune-and-biological Products of \\ Russian Academy of Sciences, Moscow, Russia \\ 5 Immanuel Kant Baltic Federal University, Kaliningrad, Russia \\ 6 The National Medical Research Center for Endocrinology, Moscow, Russia \\ 7 I. Mechnikov Research Institute of Vaccines and Sera \\ 8 Institute of Biomedical Chemistry, Moscow, Russia \\ * For full guidelines please refer to: ilyamitozubarev@gmail.com and nick.a.barlev@gmail.com*
}

\begin{abstract}
The advancement of precision medicine critically depends on the robustness and specificity of the carriers used for the targeted delivery of effector molecules in the human body. Numerous nanocarriers have been explored in vivo, to ensure the precise delivery of molecular cargos via tissue-specific targeting, including the endocrine part of the pancreas, thyroid, and adrenal glands. However, even after reaching the target organ, the cargo-carrying vehicle needs to enter the cell and then escape from lysosomal destruction. Most of artificial nanocarriers suffer from intrinsic limitations that either prevent them from completing the specific delivery of the cargo. In this respect, extracellular vesicles (EVs) seem to be the natural tool for payload delivery due to their versatility and low toxicity. However, EV-mediated delivery is not selective and usually short-ranged. By inserting the viral membrane fusion proteins into exosomes, it is possible to increase the efficiency of membrane recognition and also ease the process of membrane fusion. This review describes the molecular details of the viral-assisted interaction between the target cell and extracellular vesicles. We also discuss the question of the usability of viral fusion proteins in developing extracellular vesicle-based nanocarriers with higher efficacy of payload delivery. Finally, this review specifically highlights the role of Gag and RNA binding proteins in RNA sorting into extracellular vesicles.
\end{abstract}

Keywords: fusion protein, extracellular vesicles, target delivery, RNA sorting

\section{Introduction}

Recent developments in precision medicine are largely due to the successful implementation of specific delivery of biologically active cargos to the target tissues. This should significantly decrease possible side effects of therapeutic agents, while maintaining the appropriate efficacy. The successful implementation of this approach into clinical use would be beneficial for the treatment of a broad spectrum of various diseases, ranging from cancer, to bone fractures, or monogenic diseases. Targeted delivery may be implemented by using various carriers such as viral vectors, liposomes, nanoparticles, extracellular vesicles (EVs) and other artificial vectors. Natural carriers such as viruses or extracellular vesicles provide an effective alternative to artificial nano-carriers, as they have innate tropism to particular tissues. The best example of such carriers are recombinant non-replicating viral vectors. They have been extensively studied as promising tools for transgene delivery. Depending on the serotype, they possess natural tropism to different organs and tissues [1]. Particular strains of adeno-associated viruses (AAVs) were used 
in clinic for tissue-specific delivery to the intestines, pancreas, salivary glands, and maxillary sinus [2]. However, the capsid proteins may trigger intracellular and extracellular antiviral responses [3]. To this end, their immunogenicity may be reduced by using the methods of genetic engineering and synthetic biology. These achievements open up new possibilities for in vivo and in vitro delivery systems [4-6].

Notwithstanding the recent advances in the development of new biomaterials and nanofabrication, there are still many problems to be solved before the next generation of "smart" nanocarriers may be applied in everyday clinical practice. Their surface should be modified appropriately by various targeting molecules that would confer the affinity of nano-vehicles for specific tissues. One of the major obstacles is that higher vertebrates have various barriers that prevent the invasion of foreign materials, including nanosized delivery systems. Immune cells efficiently recognize and phagocyte the foreign biomaterial. At the same time, blood enzymes alter the structure and biological properties of these exogenous particles [7]. Although the small size of nanoparticle vectors facilitates their permeability, it also leads to delayed toxic effects [8,9]. Besides, they have poor site-specific accumulation, and are incapable of effective penetration through the tumour microenvironment [10]. Even when delivered to the target organ, the payload will not necessarily be able to efficiently enter the cells.

Many studies in this field have been focused on the development of lipid-based systems such as liposomes and lipid nanoparticles. One of the main problems with such systems is their failure to naturally fuse with cell membranes. Usually, they enter a cell via an endocytosis-based pathway. Natural carriers such as exosomes, on the contrary, have a complex surface composition with a specific set of membrane proteins that assist efficient targeting and entrance into the cells. When enriched with small non-coding RNAs (including miRNAs), mRNAs, fragments of DNA, or proteins [11-13], exosomes can be employed for targeted gene repression and cell reprogramming [14]. It has been shown that exosomes can be used as therapeutic delivery systems to treat various pathologies [15]. However, exosomes themselves do not actively promote membrane fusion, which is an important step for the efficient delivery of the drug payload into the target cell [16].

The most common way for nanoparticle vectors to enter the cell is via the endosomal pathway. In this case, loaded therapeutic molecules interact with the endosomal, and then lysosomal, environment. The latter is characterized by high acidity and high protease activity, which may alter the structure or properties of the delivered therapeutic molecules [17]. The endosomal pathway can be bypassed via fusion with the target cell, however, this process requires the breaking of the energy barrier that prevents the fusion of two lipid bilayers of interacting biological systems $[18,19]$. Even close and stable contacts between membranes under physiological conditions usually do not lead to membrane fusion. Many attempts have been made to increase the specificity of the interaction between liposomes or lipid nanoparticles with the target cells by attaching oligopeptides, antibodies or receptors. However, the efficacy of these strategies has been invariably low. The presence of a temporary contact between the two lipid bilayers does not ensure their effective fusion [20]. Altering the lipid composition of membranes or modifications thereof with different energy-decreasing molecules enhances their nonspecific fusion with other membranes [21,22]. Thus, it does not come as a surprise that liposome-based strategies have very limited efficacy for systemic delivery.

Cell to cell communication is carried out through direct interaction, secretion of various soluble factors or different cell vesicles that can have an impact on other cells. Such vesicles regulate fundamental biological properties in multiple ways, merging their membrane contents into the recipient cell plasma membrane and delivering effectors including transcription factors, oncogenes, small and large non-coding regulatory RNAs, mRNAs and infectious particles into recipient cells. Among the various articles considering exosomes as delivery vehicles, the emphasis is usually made on the content of vesicles, their distribution throughout the body, but not on the mechanism of their entry into cells [23-25]. As with liposomes, exosomes need to bypass the endosomal pathway and avoid degradation in lysosomes, which can be achieved through membrane fusion. Here, we focus 
on the mechanism of the fusion between the cell and drug-loaded extracellular vesicles and exosomes. This information may help to design novel approaches for the specific and efficient delivery of the molecular load, in particular miRNA, to manipulate the gene expression in the target cells.

\section{The process of membrane fusion: breaking the energy barrier}

The lipid bilayer of liposomes, lipid nanoparticles, and biological membranes consists of charged polar heads surrounded by a hydration layer, and neutral tails oriented towards each other. Regardless of the complexity of the system, the fusion of two membranes is accompanied by the interaction of various surface forces: hydration repulsion, hydrophobic attraction, and the Van der Waals force [26]. When put in proximity, the two lipid bilayers are weakly attracted by a weak Van der Waals force and are strongly repulsed due to the interaction of phospholipid polar groups and the hydrated shells. The fusion is the result of the hydrophobic attraction of the internal hydrophobic groups, which are surrounded by an aqueous environment. When cells form intercellular contacts, the distance between them shrinks until a thin layer of water molecules remains, and membrane fusion does not occur [19]. Each water molecule can form up to four bonds with the surrounding water molecules. Since the water molecules have an affinity for hydrophilic groups of phospholipids, they tend to form an ordered layer of charged molecules on the membrane surface. As a result, two hydrated bilayers of contacting membranes simultaneously experience a strong repulsion and a weak attraction to each other. The "hydration force" increases sharply when the distance between the surfaces of two bilayers becomes less than $20 \AA$, and the membranes get attracted to each other [27].

The energy barrier to the formation of the water-free lipid conformation is directly proportional to the intermembrane distance. Shortening the distance between the membranes leads to an attenuation of the repulsive forces between them. Membranes must stay in close juxtaposition and become destabilized to allow the transition from the bilayer to the non-bilayer conformation. During the membrane interaction, the lipid bilayer undergoes perturbation and destabilization, which causes high local curvature and membrane fusion [18]. When the membranes are close to each other in the contact area with an infinitely small radius, it leads to the dehydration of their surfaces and the formation of a fusion pore [28]. Next, a water bridge is formed and the internal contents of the two structures fuse together [29]. The process of membrane fusion itself is composed of two stages: hemifusion and pore formation. The hemifusion stage includes the merging of the outer leaflets of the opposing bilayer, whereas inner leaflets do not merge. During the pore formation, both outer and inner leaflets fuse, forming a connection between the two integrating compartments [30].

From an evolutionary point of view, membrane fusion has been developed as a well-controlled process, while random fusions could lead to serious problems for the multicellular organism [19,31,32]. Specifically, an uncontrolled fusion may lead to the formation of syncytial organisms, for which multicellularity and cell diversity is impossible. In biological systems, the fusion of membranes is implemented by conformational changes of specific fusion proteins [33]. Enveloped viruses presumable were the first living entities that were able to overcome the high-energy barrier to fuse with biological membranes using special viral fusion proteins (spikes) [34] (Fig. 1). The spike typically consists of an outer subunit that binds to the target molecule on the surface of the host cell and a transmembrane subunit which mediates the membrane fusion. The activity of fusion proteins is strongly regulated during the course of infection. For instance, they are inactivated during the biogenesis and transport of the viral particles. The insertion of the fusion protein subunit into the outer leaflet of the target membrane may be exerted in a monomeric or trimeric conformation [35]. The trimerization is mediated by the membrane interaction [36]. Albeit differing from each other in the prefusion form, all post-fusion 3D structures of viral fusion proteins show a trimeric hairpin conformation [37]. 


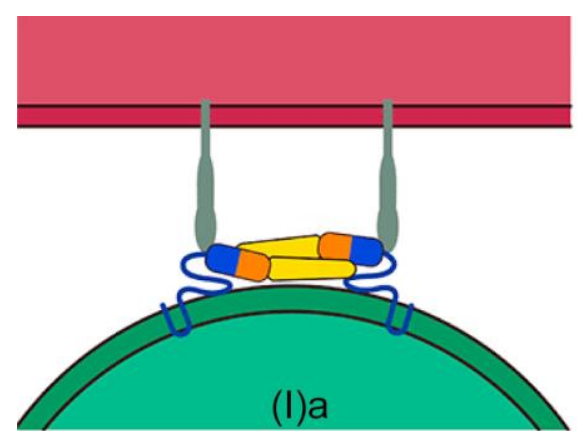

Receptor binding

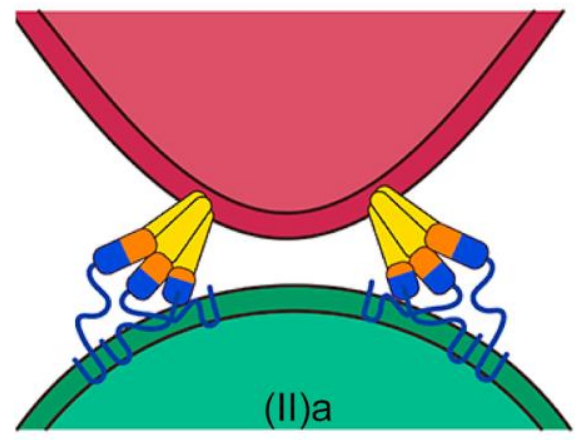

Foldback of the fusion domain

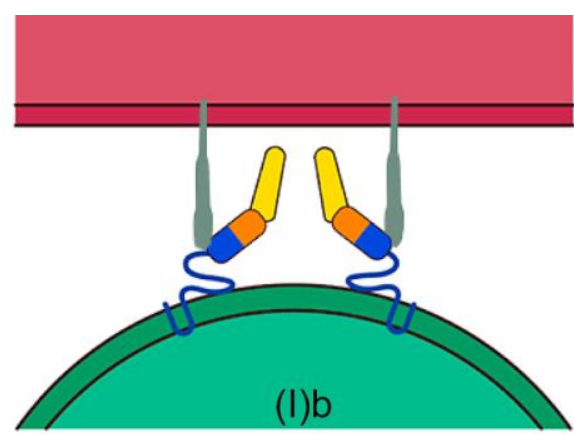

Protein dimerisation promotes the oncoming of membranes

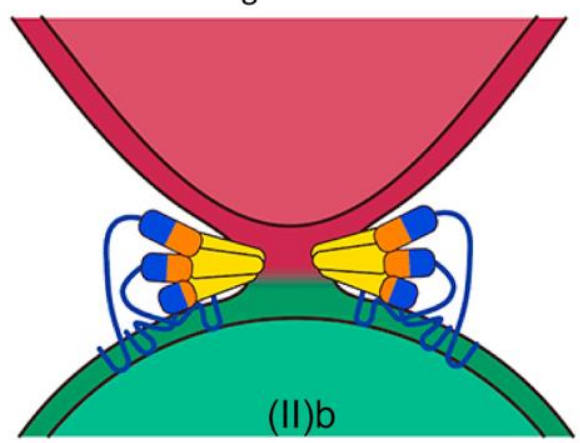

Hemifusion

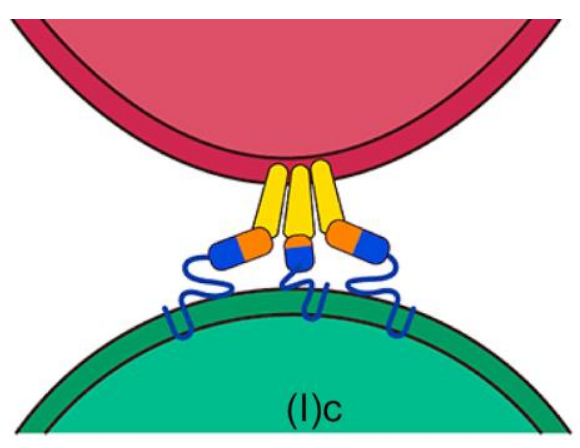

Trimerisation of the fusion protein

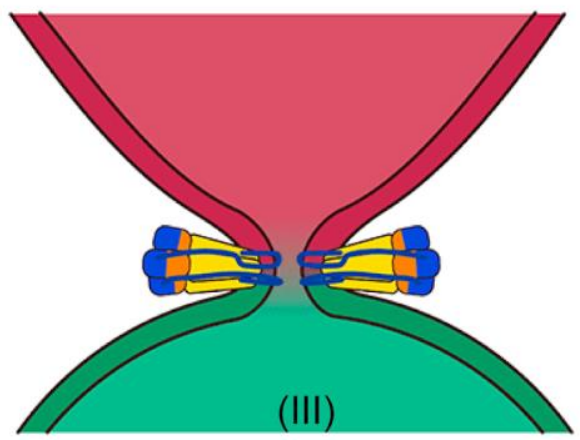

Fusion

Figure 1. Molecular mechanisms of membrane fusion. Fusion proteins (shown in multicolour monomers) in viral particles (shown in green) recognize the target molecule (shown in grey) on the cell surface (shown in red). A change in the conformation of fusion proteins is required for pore formation. This process includes several stages: (i) membrane recognition (Ia), docking (Ib) and trimerization (lc), membrane approaching (IIa), deformation, destabilization (IIb), and fusion pore formation (III) and its growth. The latter leads to the merging of the two compartments.

The energy barrier for hemifusion is estimated to be $\approx 50 \mathrm{kcal} / \mathrm{mol}$. Therefore, membranes are unable to fuse under normal conditions [38,39]. In biological systems, this process is accelerated by viral fusion proteins (Harrison 2015). For example, an individual hemagglutinin (HA) fusion peptide has the free binding energy for connecting a lipid bilayer of about $8 \mathrm{kcal} / \mathrm{mol}$. Thus, the pull force of three fusion peptides in the trimeric state is estimated as $24 \mathrm{kcal} / \mathrm{mol}$. Therefore, a triple trimeric HA should generate enough force to overcome the kinetic barrier of hemifusion (50-70 kcal/mol) [40]. Notably, for the West Nile virus and Kunjin virus the critical number of trimers to overcome the barrier was reported as two [41]. Despite the fact that the common fusion rate depends on the threshold number of adjacent trimers, a correlation between fusion peptide insertion depth and fusion effectiveness has also been demonstrated. A deeper protrusion of the fusion peptide into the target cell membrane results in a more effective fusion [42]. At the intermediate insertion depth of fusion peptides, a periodic opening and closing of a pore in the target membrane is possible. It is the secondary structure of the protein rather than the primary amino acid sequence that determines the depth of its insertion [43]. The trimerization of fusion proteins determines the effective surface abundance of activated monomers in the contact zone between membranes and is the ratelimiting stage of the fusion processes.

The onset of the fusion process initiates conformational changes in the virus fusion protein. A trimeric intermediate brings together the target cell and viral membranes and then folds back to a hairpin conformation. The trimer penetrates the target membrane via a hydrophobic loop domain, which leads to the deformation of the two membranes [44] and to the formation of a lipidic stalk or hemifusion intermediate [45]. The latter is driven by the fold-back process through the energy of protein refolding [46]. In this state, the mixing of the outer membrane 
leaflets (a stage of hemifusion) is initiated, followed by the opening of a small fusion pore. This leads to a complete compartment fusion [33]. Thus, entry into the cell can be provided by fusion proteins, whereas the correct recognition can be achieved by specific receptors on the surface of target cells.

Several mechanisms for the activation of viral fusion proteins have been described. They include receptor binding (retroviruses, lyssaviruses), receptor binding to a separate attachment protein (paramyxoviruses), the binding of a receptor with a coreceptor (HIV), low pH (alphaviruses, flaviviruses, and influenza virus), and receptor binding under low $\mathrm{pH}$ (avian sarcoma/leukosis virus). All these signals trigger the thermodynamically favoured process of the refolding of the fusion protein into a stable final post-fusion form [33]. In the first case, the binding of the viral fusion protein to the target cell triggers endocytosis allowing viruses to enter the endosome. Under a low $\mathrm{pH}$, fusion proteins undergo conformational changes that lead to the fusion with endosomes from the inside [47]. Other activation mechanisms of the fusion proteins likely involve co-receptor(s) located on the surface of the target cells [18]. For example, conformational changes in the HIV-1 gp120 protein triggered by binding to the CD4 receptor and co-receptor (e.g., CCR5 or CXCR4) leads to the refolding of the gp41 protein, and subsequently, to membrane fusion [48].

\section{Eukaryotic orthologues of viral fusion proteins}

Importantly, similar to the viral fusion proteins described above, eukaryotic cells have their own special proteins that are able to merge membranes. Several genes that are involved in the process of membrane fusion during embryo differentiation and development were originally acquired from viruses. Endogenous retroviral genes are involved in syncytium formation and cell fusion. Inside the syncytium, all cells are connected through channels that have high permeability for macromolecules, allowing them to spread between neighbouring cells. In the terminal differentiation, the lens fibres are deprived of organelles and form syncytia, while adjacent immature fibres ensure the diffusion of nutrients [49]. During the embryogenesis or regeneration of striated muscle tissue, the precursors of these cells fuse with each other to form a muscle fibre. Muscle formation is assisted by Duf and Sns proteins that exhibit the membrane attachment and fusion activities [50]. The role of fusion proteins in the origin of the sexual reproductive process has also been proposed. Structural and phylogenetic analysis of HAP2 sperm-egg fusion proteins revealed that they are homologous to the fusion proteins of the Zika and Dengue viruses [51]. HAP2 proteins and the class II viral fusogens have similar structural properties as they insert into the host cell membrane and destabilize it at the late stages of gamete fusion [52]. Summing up these facts, it is tempting to speculate that the horizontal transfer of viral fusion genes has contributed to the development of sexual reproduction [53] thereby allowing the formation of complex multicellular organisms [54]. ERV genes exert many functions in the development, including gene activation in a zygote after fertilization [55], promotion of placenta development, protection of the host from infection, and regulating the genome plasticity [56]. The syncytin-2 protein (HERV-FRD) is an immunosuppressant, whose immunosuppressive domain helps the foetus to escape the mother's immune system [57]. Syncytin-1 (HERV-W) participates in the formation of placental trophoblast, which is in turn is involved in the fusion of cancer cells and human osteoclasts [58]. The viral fusion proteins are deeply integrated into many morphogenetic processes important for the normal body functioning.

\section{Exploitation of the host mechanisms: Extracellular vesicles for infection}

The common way to transmit viruses among the host's cells is to assemble particles intracellularly and then release them into the extracellular environment. However, during the infection, virus-infected cells can fuse and form syncytia. Also, viruses can exploit existing intercellular communication pathways mediated by extracellular vesicles (EVs) to infect new populations of cells [59]. They can also be transported via extracellular vesicles [60] including exosomes - small (30-100 $\mathrm{nm}$ ) vesicles that are released by cells into the extracellular space [61]. 
Exosomes, being part of the cell-cell cargo delivery system, potentially were co-evolved together with viruses [62,63]. This fact explains many specific viral-exosome interactions and the presence of mechanisms to involvement in membrane traffic of eukaryotic cells [64]. Some non-enveloped viral particles are surrounded by cell membranes and form exosome-like vesicles that protect them from the antibody-mediated immune response (see Table 1). Different viral components of EVs may participate in the infection by assisting the targeting, internalization and replication of viruses in the target cells. The B-cell tropism of EBV gp350 in exosomes is thought to be mediated by interacting with the B lineage marker CD21 and has been applied in clinical settings [65]. Neurotropic Zika [66] and rabies viruses [67] stimulate the production of exosomes containing viral RNA and glycoproteins in neurons for further transmission. The tick-borne flaviviruses employ exosomes for the viral RNA and proteins transmission from arthropods to humans [68]. At the same time, viruses incorporate cellular proteins and nucleic acids into the EVs to escape immune response [69]. EVs could transmit viral receptors CXCR4 [70] and CCR5 [71] to healthy cells that were devoid of these receptors, making them susceptible to the infection.

Table 1. Viruses that use exosomes for cell-to-cell delivery

\begin{tabular}{|c|c|c|}
\hline Viruses & Exosome content & References \\
\hline \multicolumn{3}{|l|}{$\begin{array}{l}\text { Non-enveloped virus } \\
\text { (Exosomes-like vesicles): }\end{array}$} \\
\hline Hepatitis A, B, C & $\begin{array}{l}\text { viral particles, viral RNA, } \\
\text { proteins }\end{array}$ & {$[72-75]$} \\
\hline Poliovirus (PV) & $\begin{array}{l}\text { virions, viral RNA and } \\
\text { replication proteins }\end{array}$ & {$[76]$} \\
\hline \multicolumn{3}{|l|}{ Enveloped virus: } \\
\hline $\begin{array}{l}\text { Human immunodeficiency } \\
\text { virus (HIV) }\end{array}$ & $\begin{array}{l}\text { virus and viral constituents (such } \\
\text { as viral microRNA (miRNA), } \\
\text { viral proteins Gag and Nef }\end{array}$ & {$[77-82]$} \\
\hline Ebola virus (EBOV) & $\begin{array}{l}\text { proteins (VP40, GP, NP) and } \\
\text { RNA }\end{array}$ & {$[85]$} \\
\hline $\begin{array}{l}\text { respiratory syncytial virus } \\
(\mathrm{RSV})\end{array}$ & $\begin{array}{l}\text { different mRNA species, small } \\
\text { non-coding RNAs, nucleocapsid } \\
\text { protein } \mathrm{N} \text {, attachment protein } \mathrm{G} \text {, } \\
\text { and fusion protein } \mathrm{F}\end{array}$ & {$[86]$} \\
\hline $\begin{array}{l}\text { alpha (Herpes Simplex Virus } \\
\text { 1), beta Human } \\
\text { Cytomegalovirus, and Human } \\
\text { Herpesvirus 6), and gamma } \\
\text { (Epstein-Barr Virus, and } \\
\text { Kaposi Sarcoma-associated } \\
\text { Herpesvirus) herpesviruses }\end{array}$ & $\begin{array}{l}\text { viral DNA, mRNAs, miRNAs, } \\
\text { and some EBV proteins: EBV } \\
\text { nuclear antigen-1 (EBNA-1) and } \\
\text { latent membrane proteins } 1 \text { and } \\
2 \text { (LMP-1 and LMP-2) }\end{array}$ & {$[87-89]$} \\
\hline
\end{tabular}

Viruses exploit the Endosomal Sorting Complex Required for Transport (ESCRT) pathway to intercept cell membrane traffic. Viral structural proteins, such as retroviral Gag proteins, arenaviral Z proteins, and filoviral VP40 proteins, act as ESCRT adaptors. They interact with ESCRT components via specific sequence motifs similar 
to cell proteins [90]. Several specific motifs (P(T/S)AP, PPxY, $\Theta P x V, Y P(x) n L)$ of the viral structural proteins mediate the recruitment of the ESCRT machinery to the particle assembly sites [91-94]. In particular, many structural proteins contain the YPXL assembly domains that bind directly to the central V-domain of ALIX - the early-acting ESCRT factor [94]. Viruses that contain such YPXL domains include retroviruses, arenaviruses, flaviviruses, hepadnaviruses, herpesviruses, paramyxoviruses, and tombusviruses [94]. Nef is a scaffold protein of HIV-1, which is associated with lipid-raft microdomains during the assembly of retroviral particles [95]. To illustrate the ability of Nef to interact with sorting proteins or RNA and get loaded into exosomes a non-functional mutant of the HIV-I Nef protein (Nefmut) was used [96]. The Nefmut-GFP fusion protein was successfully loaded into exosomes [97]. Fusing Nefmut to several viral proteins, including Ebola virus VP24, VP40, and NP, influenza virus NP and others resulted in the expression of stable fusion proteins and their efficient loading into exosomes [98]. Thus, due to specific structural motifs, viral proteins stimulate the formation of extracellular vesicles to move between cells.

Viral attachment and subsequent cell entry are mediated by a number of membrane molecules located on the surface of the host cell [99]. Several classes of such molecules serve as binding factors or entry receptors that are recognized by fusion proteins of mammalian enveloped viruses (see table 2). Therefore, it is tempting to speculate that choosing the right viral protein from the broad variety of viral proteins that recognize specific cellular receptors may improve the delivery efficiency of specific transgenes.

Table 2. Viral receptors and its potential application for treatment human pathologies with overexpression of viral receptor

\begin{tabular}{|c|c|c|c|}
\hline Virus & $\begin{array}{l}\text { Receptor of fusion } \\
\text { protein }\end{array}$ & $\begin{array}{l}\text { Localization } \\
\text { Normal Cells }\end{array}$ & $\begin{array}{l}\text { Potential application for treatment human } \\
\text { pathologies with upregulation of viral } \\
\text { receptor }\end{array}$ \\
\hline Hepatitis B virus & $\begin{array}{l}\text { Sodium Taurocholate } \\
\text { Cotransporting } \\
\text { Polypeptide (NTCP) }\end{array}$ & Hepatocytes [104] & $\begin{array}{l}\text { Use in target therapy for liver fibrosis and } \\
\text { cancer [105] }\end{array}$ \\
\hline Hepatitis C virus & $\begin{array}{l}\text { CD81 tetraspanin, } \\
\text { scavenger receptor } \\
\text { class B type I (SR-B1) }\end{array}$ & Hepatocytes [106] & $\begin{array}{l}\text { CD81 increases the progression of prostate } \\
\text { cancer [107] } \\
\text { High SR-B1 expression is observe in lung } \\
\text { adenocarcinoma [108] }\end{array}$ \\
\hline $\begin{array}{l}\text { Rous sarcoma virus } \\
\text { Vesicular stomatitis } \\
\text { virus }\end{array}$ & $\begin{array}{lr}\text { Low } & \text { density } \\
\text { lipoprotein } & \text { receptor } \\
\text { (LDLR) } & \\
\end{array}$ & $\begin{array}{l}\text { Bronchial epithelial } \\
\text { cells [109] } \\
\text { Epithelial cells [110] }\end{array}$ & $\begin{array}{l}\text { Increased LDLR expression in Prostate cancer } \\
{[111] \text { and breast cancer [112] }}\end{array}$ \\
\hline $\begin{array}{l}\text { Human } \\
\text { immunodeficiency } \\
\text { viruses (HIV) }\end{array}$ & CD209, CD4 & T cells $[113]$ & $\begin{array}{l}\text { Targeting to HIV infected cells. } \\
\text { B and T cell lymphoma [114] }\end{array}$ \\
\hline $\begin{array}{l}\text { Respiratory syncytial } \\
\text { virus }\end{array}$ & IGF1R, CX3CR1 & $\begin{array}{l}\text { Bronchial epithelial } \\
\text { cells }[115,116]\end{array}$ & Broad types range of cancer [117] \\
\hline
\end{tabular}




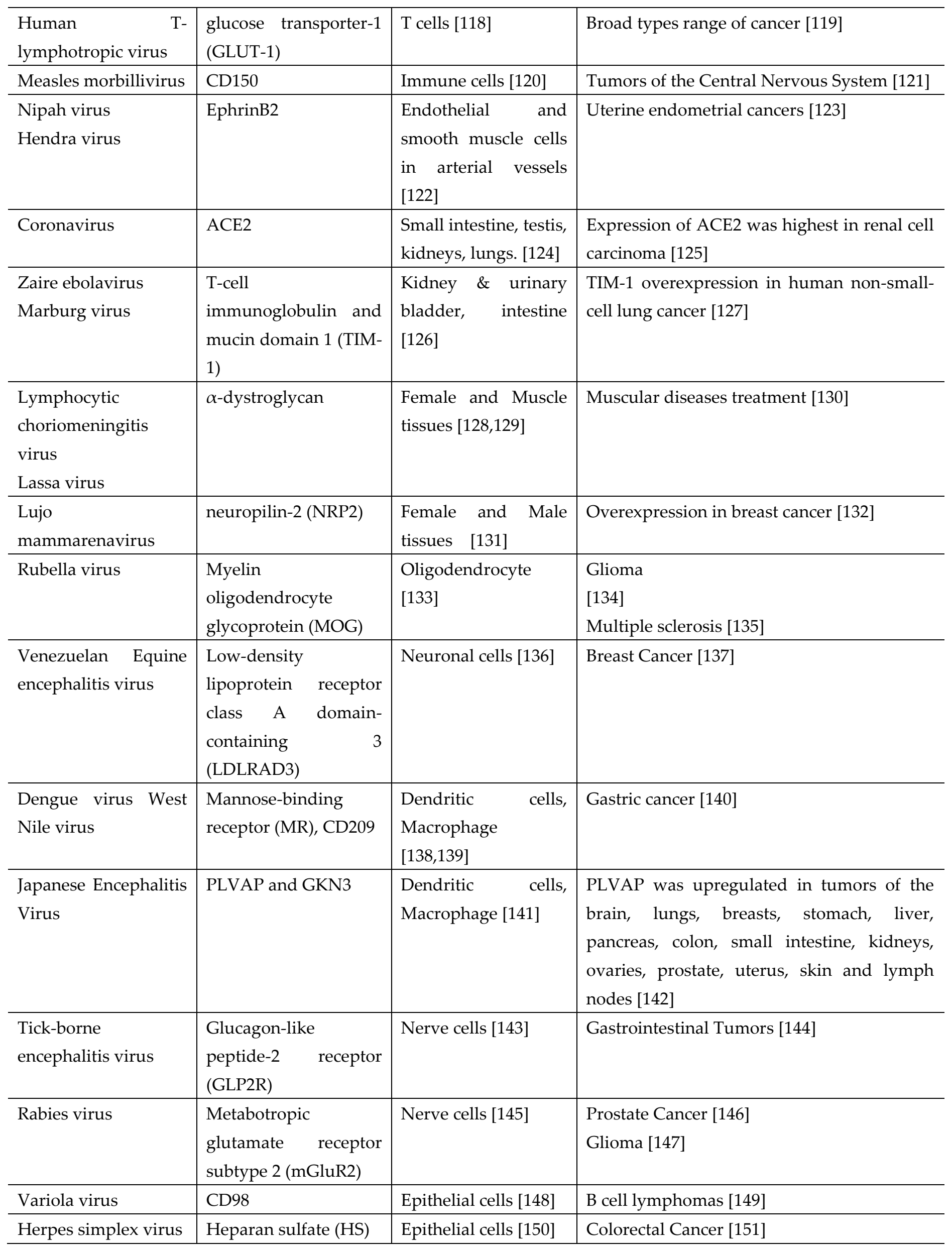




\begin{tabular}{l|l|l|l}
\hline $\begin{array}{l}\text { Mouse mammary } \\
\text { tumor virus }\end{array}$ & Transferrin receptor 1 & $\begin{array}{l}\text { Mammary epithelial } \\
\text { cells [152] }\end{array}$ & $\begin{array}{l}\text { TFR1 is abundantly expressed in liver, breast, } \\
\text { lung and colon cancer cells [153] }\end{array}$ \\
\hline Syncytin-1 & $\begin{array}{l}\text { Na-dependent amino } \\
\text { acid transporter 2 } 2\end{array}$ & $\begin{array}{l}\text { ASCT2 expression } \\
\text { increases in highly } \\
\text { (ASCT2) }\end{array}$ & $\begin{array}{l}\text { Colorectal Cancer [155] } \\
\text { proliferative cells } \\
\text { such as inflammatory } \\
\text { and stem cells [154] }\end{array}$ \\
\hline
\end{tabular}

Viral pseudogenes are involved in the building of syncytia in muscles, osteoclasts, the lens, placenta, embryonic ovaries, testes, sexual reproduction. However, there is only a limited number of organs with syncytia, which restricts the use of human fusion proteins for the vesicle-mediated targeted delivery. Therefore, the idea of targeting extracellular vesicles and exosomes with synthetic viral fusion proteins seems to be worthy of experimental testing. If this approach proves efficient, it would help to expand the application and efficacy of these systems by allowing them to escape degradation in the course of the endosomal pathway [156].

Altogether, numerous variants of viral capsid proteins provide a new platform for using viral tropism as a tool for selective tissue-specific recognition and merging with the target cells. As a new approach in cancer immunotherapy, it was proposed to use tumor xenogenization (a process of addition of the pathogenic antigen that increases the visibility of cancer cells for the host immune system) through fusogenic exosomes with special fusogenic viral antigens (e.g. VSV-G). Ideally, this approach would enhance the recognition and uptake by dendritic cells, which would then recruit T-lymphocytes and ultimately result in the suppression of tumour growth $[157,158]$. The same VSV-G protein was applied as part of virus-mimetic fusogenic exosomes for the insertion of integral proteins of interest into the target membrane [159,160]. The presence of not only VSV-G but other viral envelope proteins on the EV's membrane stimulates specific attachment and fusion with target cells [161,162]. For example, the Lamp $2 b$ protein fused with the neuron-specific rabies viral glycoprotein (RVG) peptide can efficiently target neurons [163]. Extracellular vesicles with the receptor-binding domain (RBD) of the viral spike protein and siRNAs against SARS-CoV-2 can specifically recognize the ACE2 receptor on the surface of target cells. These EVs can be effectively used in vivo for attachment, fusion and cellular entry during delivery of potential antiviral agents which as a therapeutic potential against SARS-CoV-2 infection [164]. Human fusion proteins are also involved in the intercellular communication through fusogenic exosomes, for example, in intercellular communication in the placenta [165] and muscles [166].

Another way of increasing the specificity of exosome targeting can be achieved via the insertion of specific integrins into membranes of exosomes. Integrins are heterodimeric cell membrane proteins consisting of $\alpha$ and $\beta$ subunits. The major biological role of integrins is to mediate cell-cell contacts at specific focal adhesion points. Importantly, integrins transmit transmembrane signals bi-directionally thereby modulating the intracellular events in response to specific ligands. During the formation of exosomes, integrins are captured on their surface. Consistent with their functions, exosomal integrins have been shown to be capable of guiding exosomes to specific tissues. In the pioneering work, Lyden's group have shown that exosomes derived from breast and pancreatic cancer cells ectopically expressing integrin $\alpha 6 \beta 4$ were preferentially targeted to the lung tissue since the latter expresses laminin, the ligand for the $\alpha 6 \beta 4$ integrin. On the contrary, those exosomes that expressed integrin $\alpha \mathrm{V} \beta 5$, which specifically recognizes fibronectin, were preferentially distributed to the liver cells, which are known to abundantly express this ECM protein [167]. Thus, one would predict that an artificial embedding of specific integrins into the membrane of EVs should increase the tropism of exosomes to specific tissues. 


\section{Exploitation of viral sorting mechanisms for RNA loading into extracellular vesicles}

Exosomes, especially the ones derived from cancer tissues, are deemed to affect the physiology of target cells [168]. It is known that the majority of vesicular RNAs are non-coding RNAs (ncRNAs) including tRNAs, rRNAs, microRNAs, and small nuclear RNAs [169]. ncRNAs act as important mediators of the intracellular communication through the regulation of energy metabolism and cell-to-cell signalling [170]. Therefore, ncRNA-loaded EVs may be of interest from the therapeutic point of view.

Loading of RNA into EVs can occur in several ways: randomly, due to the abundance of certain RNA species in the cytosol or selectively, by RNA-binding proteins (RBPs) that recognize specific motifs / secondary structures in the RNAs to be sorted. These RBPs recognize specific (GAGAG [171] and GGAG [172]) sequence motifs in miRNA or UTR in mRNA as EV packaging signals. The group of RBPs responsible for sorting RNAs into EVs is heterogeneous and includes many proteins, e.g. AGO2/Argonaute [173], ALIX70 [174], annexin A2 [175], major vault protein (MVP) [176], the human antigen $\mathrm{R}(\mathrm{HuR})$ [177], heterogeneous nuclear ribonucleoproteins [172], FMR1 [178], hnRNPU [179] to name just a few [180].

Viruses possess a unique system of specific recognition and packaging only the viral RNA into a viral particle despite the fact that there are thousands of mRNAs in the animal cell [181]. This specificity is ensured by the recognition of a special 3'-UTR or 5'-UTR RNA packing signal by Gag proteins [182]. The gag protein binds to the cis-acting RNA element or psi packaging sequence (known as $\Psi$ ) in the $5^{\prime}$ untranslated region (UTR) through the NC domain [183,184]. The packaging signal (the psi region) folds into four stem-loop structures (SL1, SL2, SL3, SL4) $[185,186]$. A minimal 159-nt RNA sequence that includes SL1-SL3 can dimerize and is competent to bind gag NC and is sufficient to induce packaging of an any RNA sequence with the psi signal [187]. Mutagenesis studies suggested that it is the structure of the $\Psi$ hairpin, rather than its sequence is critical for genome dimerization and packaging [188]. The packaging signal consists not merely of the linear RNA sequence of $\psi$, but also includes the 3-dimensional structure formed upon dimerization. The presence of two packing signals on one mRNA molecule induces packing in the form of monomers [189].

The psi signal of RNA can be recognized by special viral proteins, in particular the gag protein. There are four key domains found in all Gag proteins (listed N- to C-terminus): the matrix (MA) domain, which is primarily associated with membrane-binding capability; the capsid (CA) domain, which mediates numerous Gag-Gag interactions; the nucleocapsid (NC) domain, which is involved in specifically packaging the genome RNA (gRNA); and p6 contributes to the release of the assembled particle from the host cell by interacting with the cellular endosomal sorting complexes required for transport (ESCRT) machinery [190]. The NC domain specifically interacts with the G-rich and G/U-rich sequence motifs of gRNA through two evolutionarily conserved Cys-His boxes with Zn2+ ions, allowing for high-affinity NC-gRNA interactions [191,192].

Recombinant Gag proteins can assemble into particles in vitro, but this assembly requires the addition of nucleic acids; nearly any single-stranded nucleic acid longer than 20-30 nucleotides can support assembly under these conditions [193]. Using gRNA of different lengths ( $3 \mathrm{~kb}, 8 \mathrm{~kb}$, or $17 \mathrm{~kb}$ ), it was shown that binding to nucleic acid primes Gag assembly, indicating that viral genome packaging is not regulated by the RNA mass [194]. RNAs can serve as a scaffold for Gag proteins to assemble whereas NC binds to RNA, and this interaction leads to the multimerization of the Gag polyproteins [195]. RNA binding proteins anchor to the plasma membrane, oligomerize and induce the release of vesicles by budding from the plasma membrane [196].

There are $~ 100$ retroviral Gag-like genes in the human genome that can self-assemble into RNA-carrying capsids [197]. Notably, its Gag domain could bind to UTR of some RNA and drive the extraction of extracellular vesicles or viral-like particles. It has been suggested that synthetic RNA-sorting can be programmed by inserting appropriate retroviral elements. Some retroviral-like Gag proteins (e.g. Arc) can bind RNA and produce extracellular vesicles by multimerizing into virus-like capsids similar to the viral RNA packaging [198]. Notably, 
the Peg10 (paternally expressed gene 10) gene, originally of the viral origin, plays an important role in the placental development. Nevertheless, Peg10 also maintains the ability to bind and package its own mRNA. This finding allowed to create an artificial packaging system where heterologous RNAs fused with Peg10-3'UTR were efficiently packed by Peg10 [199,200]. Furthermore, using the viral RNA packaging system it became possible to specifically incorporate sgRNA with the CRISPR-Cas9 nuclease into extracellular vesicles for genome editing [201]. Thus, an in-depth understanding of the viral genome packaging mechanisms should aid in developing an effective platform for RNA delivery and expand the repertoire of gene therapy applications.

\section{Conclusions and perspectives}

An understanding of mechanisms membrane fusion and RNA sorting promises new approaches to control the loading of extracellular vesicles with specific RNAs. More specifically, the recognize of the RNA packaging signal by the RNA-binding domain of synthetic viral-like proteins may assist the loading of mRNA and miRNA of interest into the extracellular vesicles (Fig. 2). To this end, it is possible to create a cell line with constitutive coexpression of the viral fusion protein and the RNA binding protein to assist the production of targeted extracellular vesicles. Such extracellular vesicles should be biosafe as they will not contain the whole viral genome and will only be weakly immunogenic. However, for the therapeutic purposes a high yield of extracellular vesicle production must be obtained. The production of large quantities of pure extracellular vesicle requires a large amount of primary cell material. Increasing the biogenesis of extracellular vesicles using special viral proteins in the producer cells is one of the viable approaches to increase the quantities of RNA-containing extracellular vesicles [159].

A

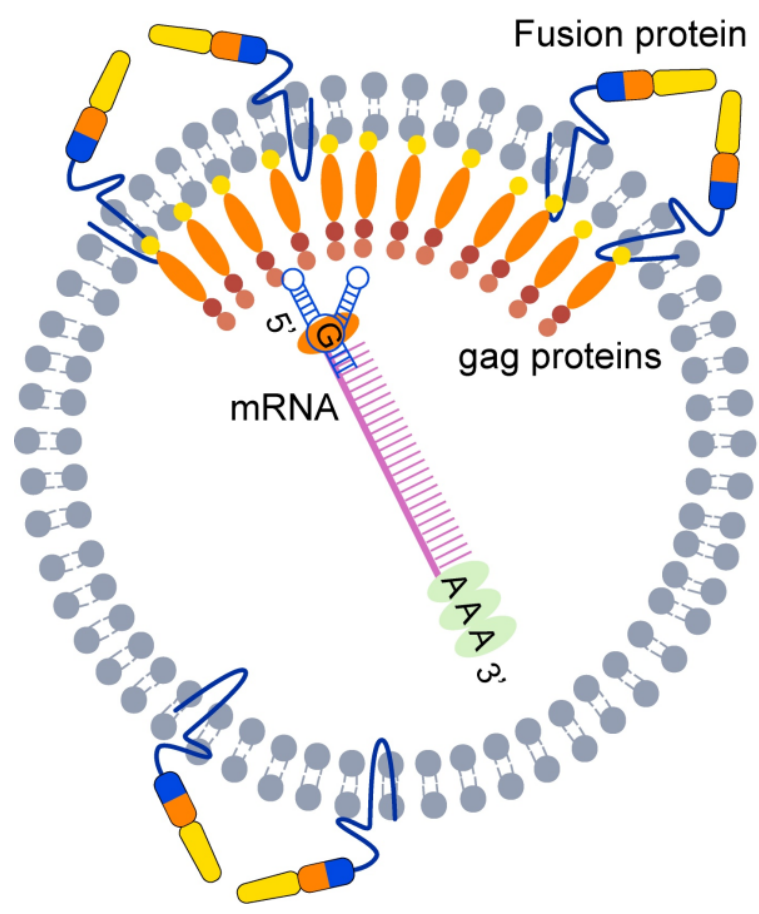

B

\section{Extracellular vesicle with engineered fusion protein}

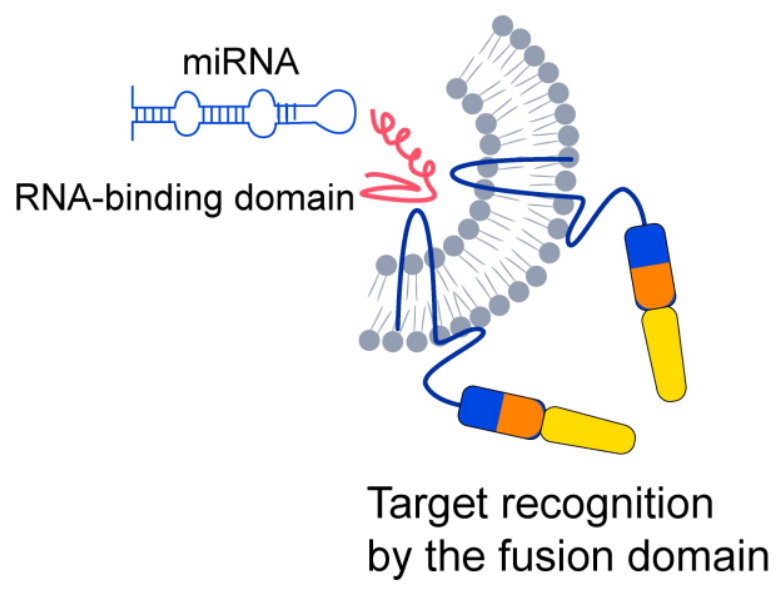

Figure 2. Extracellular vesicles functionalised with fusion proteins. A. Design of a system for sorting mRNA into extracellular vesicles using viral gag protein and the packing signal. The gag protein selectively binds the packaging signal and saturates the vesicles with mRNA. B. The EV vector may be functionalized with an engineered fusion protein (shown in multicolour monomers) that contains an RNA binding domain (shown in red). The intravesicular domain of fusion proteins consists of an RNA-binding domain (RBD) that can bind specific miRNAs with the packaging signal. The RNA packaging signal is recognized by the RBD of fusion proteins and 
may stimulate the upload of miRNA into extracellular vesicles. Fusion proteins may interact with an extravesicular recognition domain and form the structure required for merging with the target membrane.

Given the fact that the HIV genome $(9.8 \mathrm{~kb})$ can be packed within the volume of the exosome size, one should potentially be able to pack 500 copies of miRNAs into a single exosome [202]. Furthermore, enveloped coronaviruses have virion sizes similar to those of extracellular vesicles and contain single-stranded RNA up to 30 $\mathrm{kb}$ in size. This is the largest known genome size of an RNA virus and can serve as a guideline for the maximum RNA capacity of these extracellular vesicles.

We hypothesize that the expanding knowledge of different mechanisms that viruses utilize to interact with host cells, together with the ability to manipulate and engineer hybrid extracellular vesicles, could be the basis for the development of future therapies. In fact, effective targeting delivery systems have already been developed by viruses in the course of evolution, which can specifically navigate through the human body. Therefore, the success of future studies relies on the ability to repurpose the already available delivery systems for the benefit of human health.

Funding This work was supported by the Ministry of Science and Higher Education of the Russian Federation (75-15-2020-913)

Authors' contributions I. Zubarev: Conceptualization, Project administration, Writing; D. Vladimirtsev: Writing; M. Vorontsova: Writing; I. Blatov: Writing; K. Shevchenko: Writing; S. Zvereva: Writing; E. Lunev: Writing; E. Faizuloev: Writing; N. Barlev: Funding acquisition, Writing

Acknowledgements. We thank Elmira Yakupova (yakupova.mira@mail.ru) for assistance with the illustrations used in this review. We acknowledge the financial support by the Ministry of Science and Higher Education of the Russian Federation within the framework of state support for the creation and development of World-Class Research Centers “Digital biodesign and personalized healthcare” No. 75-15-2020-913

Conflict of Interest The authors declare that the research was conducted in the absence of any commercial or financial relationships that could be construed as a potential conflict of interest.

\section{References}

1. Wilson, R.C.; Gilbert, L.A. The Promise and Challenge of in Vivo Delivery for Genome Therapeutics. ACS Chem. Biol. 2018, 13, 376-382, doi:10.1021/acschembio.7b00680.

2. Kimura, T.; Ferran, B.; Tsukahara, Y.; Shang, Q.; Desai, S.; Fedoce, A.; Pimentel, D.R.; Luptak, I.; Adachi, T.; Ido, Y.; et al. Production of adeno-associated virus vectors for in vitro and in vivo applications. Sci. Rep. 2019, 9(1), 13601, doi:10.1038/s41598-019-49624-w.

3. Duan, D.; Yue, Y.; Yan, Z.; Yang, J.; Engelhardt, J.F. Endosomal processing limits gene transfer to polarized airway epithelia by adeno-associated virus. J. Clin. Invest. 2000, 105, 1573-1587, doi:10.1172/JCI8317.

4. Markusic, D.M.; Herzog, R.W.; Aslanidi, G. V.; Hoffman, B.E.; Li, B.; Li, M.; Jayandharan, G.R.; Ling, C.; Zolotukhin, I.; Ma, W.; et al. High-efficiency transduction and correction of murine hemophilia B using AAV2 vectors devoid of multiple surface-exposed tyrosines. Mol. Ther. 2010, 18(12), 2048-56, doi:10.1038/mt.2010.172.

5. Zhong, L.; Li, B.; Jayandharan, G.; Mah, C.S.; Govindasamy, L.; Agbandje-McKenna, M.; Herzog, R.W.; WeigelVan Aken, K.A.; Hobbs, J.A.; Zolotukhin, S.; et al. Tyrosine-phosphorylation of AAV2 vectors and its consequences on viral intracellular trafficking and transgene expression. Virology 2008, 381, 194-202, 
doi:10.1016/j.virol.2008.08.027.

6. Li, C.; Samulski, R.J. Engineering adeno-associated virus vectors for gene therapy. Nat. Rev. Genet. 2020, 21, 255272.

7. Engin, A.B.; Hayes, A.W. The impact of immunotoxicity in evaluation of the nanomaterials safety. Toxicol. Res. Appl. 2018, 2, 239-244, doi:10.1177/2397847318755579.

8. Li, X.; Liu, X.; Huang, J.; Fan, Y.; Cui, F. zhai Biomedical investigation of CNT based coatings. Surf. Coatings Technol. 2011, 206(4), 759-766, doi:10.1016/j.surfcoat.2011.02.063.

9. Meng, H.; Leong, W.; Leong, K.W.; Chen, C.; Zhao, Y. Walking the line: The fate of nanomaterials at biological barriers. Biomaterials 2018, 174, 41-53, doi:10.1016/j.biomaterials.2018.04.056.

10. Al-Maawi, S.; Orlowska, A.; Sader, R.; James Kirkpatrick, C.; Ghanaati, S. In vivo cellular reactions to different biomaterials-Physiological and pathological aspects and their consequences. Semin. Immunol. 2017, 29, 49-61, doi:10.1016/j.smim.2017.06.001.

11. Valadi, H.; Ekström, K.; Bossios, A.; Sjöstrand, M.; Lee, J.J.; Lötvall, J.O. Exosome-mediated transfer of mRNAs and microRNAs is a novel mechanism of genetic exchange between cells. Nat. Cell Biol. 2007, 9, 654-659, doi:10.1038/ncb1596.

12. Shurtleff, M.J.; Yao, J.; Qin, Y.; Nottingham, R.M.; Temoche-Diaz, M.M.; Schekman, R.; Lambowitz, A.M. Broad role for YBX1 in defining the small noncoding RNA composition of exosomes. Proc. Natl. Acad. Sci. U. S. A. 2017, 114, E8987-E8995, doi:10.1073/pnas.1712108114.

13. Thakur, B.K.; Zhang, H.; Becker, A.; Matei, I.; Huang, Y.; Costa-Silva, B.; Zheng, Y.; Hoshino, A.; Brazier, H.; Xiang, J.; et al. Double-stranded DNA in exosomes: A novel biomarker in cancer detection. Cell Res. 2014, 24, 766-769.

14. Pegtel, D.M.; Cosmopoulos, K.; Thorley-Lawson, D.A.; Van Eijndhoven, M.A.J.; Hopmans, E.S.; Lindenberg, J.L.; De Gruijl, T.D.; Würdinger, T.; Middeldorp, J.M. Functional delivery of viral miRNAs via exosomes. Proc. Natl. Acad. Sci. U. S. A. 2010, 107, 6328-6333, doi:10.1073/pnas.0914843107.

15. Sarko, D.K.; McKinney, C.E. Exosomes: Origins and therapeutic potential for neurodegenerative disease. Front. Neurosci. 2017, 11, 82-90.

16. Antimisiaris, S.G.; Mourtas, S.; Marazioti, A. Exosomes and exosome-inspired vesicles for targeted drug delivery. Pharmaceutics 2018, 10, 218-220.

17. Straubinger, R.M.; Hong, K.; Friend, D.S.; Papahadjopoulos, D. Endocytosis of liposomes and intracellular fate of encapsulated molecules: Encounter with a low $\mathrm{pH}$ compartment after internalization in coated vesicles. Cell 1983, 32, 1069-1079, doi:10.1016/0092-8674(83)90291-X.

18. Harrison, S.C. Viral membrane fusion. Virology 2015, 479-480, 498-507, doi:10.1016/j.virol.2015.03.043.

19. Martens, S.; McMahon, H.T. Mechanisms of membrane fusion: Disparate players and common principles. Nat. 
Rev. Mol. Cell Biol. 2008, 9, 543-556.

20. Wilschut, J.; Hoekstra, D. Membrane fusion: from liposomes to biological membranes. Trends Biochem. Sci. 1984, 9, 479-483, doi:10.1016/0968-0004(84)90316-5.

21. Kube, S.; Hersch, N.; Naumovska, E.; Gensch, T.; Hendriks, J.; Franzen, A.; Landvogt, L.; Siebrasse, J.P.; Kubitscheck, U.; Hoffmann, B.; et al. Fusogenic liposomes as nanocarriers for the delivery of intracellular proteins. Langmuir 2017, 33, 1051-1059, doi:10.1021/acs.langmuir.6b04304.

22. Yang, J.; Bahreman, A.; Daudey, G.; Bussmann, J.; Olsthoorn, R.C.L.; Kros, A. Drug delivery via cell membrane fusion using lipopeptide modified liposomes. ACS Cent. Sci. 2016, 2, 621-630, doi:10.1021/acscentsci.6b00172.

23. Gurung, S.; Perocheau, D.; Touramanidou, L.; Baruteau, J. The exosome journey: from biogenesis to uptake and intracellular signalling. Cell Commun. Signal. 2021, 19, 1-19, doi:10.1186/s12964-021-00730-1.

24. Kalluri, R.; LeBleu, V.S. The biology, function, and biomedical applications of exosomes. Science (80-. ). 2020, 367, 64-78, doi:10.1126/science.aau6977.

25. Pegtel, D.M.; Gould, S.J. Exosomes. https://doi.org/10.1146/annurev-biochem-013118-111902 2019, 88, 487-514, doi:10.1146/ANNUREV-BIOCHEM-013118-111902.

26. Rand, R.P.; Parsegian, V.A. Physical force considerations in model and biological membranes. Can. J. Biochem. Cell Biol. 1984, 62, 752-759, doi:10.1139/o84-097.

27. Parsegian, V.A.; Fuller, N.; Rand, R.P. Measured work of deformation and repulsion of lecithin bilayers. Proc. Natl. Acad. Sci. U. S. A. 1979, 76, 2750-2754, doi:10.1073/pnas.76.6.2750.

28. Lee, K.K. Architecture of a nascent viral fusion pore. EMBO J. 2010, 29, 1299-1311, doi:10.1038/emboj.2010.13.

29. Rand, R.P.; Parsegian, V.A. Hydration forces between phospholipid bilayers. BBA - Rev. Biomembr. 1989, 988, 351-376, doi:10.1016/0304-4157(89)90010-5.

30. Lentz, B.R.; Malinin, V.; Haque, M.E.; Evans, K. Protein machines and lipid assemblies: Current views of cell membrane fusion. Curr. Opin. Struct. Biol. 2000, 10, 607-615, doi:10.1016/S0959-440X(00)00138-X.

31. Brukman, N.G.; Uygur, B.; Podbilewicz, B.; Chernomordik, L. V. How cells fuse. J. Cell Biol. 2019, 218, 1436-1451.

32. Mayer, A. Membrane fusion in eukaryotic cells. Annu. Rev. Cell Dev. Biol. 2002, 18, 109-116.

33. Kielian, M. Mechanisms of virus membrane fusion proteins. Annu. Rev. Virol. 2014, 1, 171-189, doi:10.1146/annurev-virology-031413-085521.

34. van Dongen, H.M.; Masoumi, N.; Witwer, K.W.; Pegtel, D.M. Extracellular Vesicles Exploit Viral Entry Routes for Cargo Delivery. Microbiol. Mol. Biol. Rev. 2016, 80, 369-386, doi:10.1128/mmbr.00063-15.

35. Skehel, J.J.; Wiley, D.C. Receptor binding and membrane fusion in virus entry: The influenza hemagglutinin. Annu. Rev. Biochem. 2000, 69, 531-569, doi:10.1146/annurev.biochem.69.1.531. 
36. Stiasny, K.; Kössl, C.; Lepault, J.; Rey, F.A.; Heinz, F.X. Characterization of a structural intermediate of flavivirus membrane fusion. PLoS Pathog. 2007, 3, 0191-0199, doi:10.1371/journal.ppat.0030020.

37. Kielian, M. Mechanisms of Virus Membrane Fusion Proteins. Annu. Rev. Virol. 2014, 1, 171-189, doi:10.1146/annurev-virology-031413-085521.

38. Ryham, R.J.; Klotz, T.S.; Yao, L.; Cohen, F.S. Calculating Transition Energy Barriers and Characterizing Activation States for Steps of Fusion. Biophys. J. 2016, 110, 1110-1124, doi:10.1016/j.bpj.2016.01.013.

39. Efrat, A.; Chernomordik, L. V.; Kozlov, M.M. Point-like protrusion as a prestalk intermediate in membrane fusion pathway. Biophys. J. 2007, 92, L61, doi:10.1529/biophysj.106.103341.

40. Li, Y.; Han, X.; Lai, A.L.; Bushweller, J.H.; Cafiso, D.S.; Tamm, L.K. Membrane Structures of the HemifusionInducing Fusion Peptide Mutant G1S and theFusion-Blocking Mutant G1V of Influenza Virus HemagglutininSuggest a Mechanism for Pore Opening in MembraneFusion. J. Virol. 2005, 79, 12065-12076, doi:10.1128/jvi.79.18.12065-12076.2005.

41. Chao, L.H.; Klein, D.E.; Schmidt, A.G.; Peña, J.M.; Harrison, S.C. Sequential conformational rearrangements in flavivirus membrane fusion. Elife 2014, 3, 43-49, doi:10.7554/eLife.04389.

42. Molotkovsky, R.J.; Galimzyanov, T.R.; Jiménez-Munguía, I.; Pavlov, K. V.; Batishchev, O. V.; Akimov, S.A. Switching between successful and dead-end intermediates in membrane fusion. Int. J. Mol. Sci. 2017, 18, 2598, doi:10.3390/ijms18122598.

43. White, J.M.; Delos, S.E.; Brecher, M.; Schornberg, K. Structures and mechanisms of viral membrane fusion proteins: Multiple variations on a common theme. Crit. Rev. Biochem. Mol. Biol. 2008, 43, 189-219.

44. Kozlov, M.M.; McMahon, H.T.; Chernomordik, L. V. Protein-driven membrane stresses in fusion and fission. Trends Biochem. Sci. 2010, 35, 699-706, doi:10.1016/j.tibs.2010.06.003.

45. Chernomordik, L. V.; Kozlov, M.M. Protein-Lipid Interplay in Fusion and Fission of Biological Membranes. Annu. Rev. Biochem. 2003, 72, 175-207, doi:10.1146/annurev.biochem.72.121801.161504.

46. Harrison, S.C. Mechanism of Membrane Fusion by Viral Envelope Proteins. Adv. Virus Res. 2005, 64, 231-261.

47. Gaudin, Y.; Ruigrok, R.W.; Knossow, M.; Flamand, A. Low-pH conformational changes of rabies virus glycoprotein and their role in membrane fusion. J. Virol. 1993, 67, 1365-1372, doi:10.1128/jvi.67.3.1365-1372.1993.

48. Pancera, M.; Zhou, T.; Druz, A.; Georgiev, I.S.; Soto, C.; Gorman, J.; Huang, J.; Acharya, P.; Chuang, G.Y.; Ofek, G.; et al. Structure and immune recognition of trimeric pre-fusion HIV-1 Env. Nature 2014, 514, 455-461, doi:10.1038/nature13808.

49. Shi, Y.; Barton, K.; De Maria, A.; Petrash, J.M.; Shiels, A.; Bassnett, S. The stratified syncytium of the vertebrate lens. J. Cell Sci. 2009, 122, 1607-1615, doi:10.1242/jcs.045203.

50. Chen, E.H.; Pryce, B.A.; Tzeng, J.A.; Gonzalez, G.A.; Olson, E.N. Control of myoblast fusion by a guanine nucleotide exchange factor, loner, and its effector ARF6. Cell 2003, 114, 751-762, doi:10.1016/S0092- 
8674(03)00720-7.

51. Valansi, C.; Moi, D.; Leikina, E.; Matveev, E.; Graña, M.; Chernomordik, L. V.; Romero, H.; Aguilar, P.S.; Podbilewicz, B. Arabidopsis HAP2/GCS1 is a gamete fusion protein homologous to somatic and viral fusogens. J. Cell Biol. 2017, 216, 571-581, doi:10.1083/jcb.201610093.

52. Podbilewicz, B. Virus and cell fusion mechanisms. Annu. Rev. Cell Dev. Biol. 2014, 30, 111-139, doi:10.1146/annurev-cellbio-101512-122422.

53. Vance, T.D.R.; Lee, J.E. Virus and eukaryote fusogen superfamilies. Curr. Biol. 2020, 30, R750-R754, doi:10.1016/j.cub.2020.05.029.

54. Soygur, B.; Sati, L. The role of syncytins in human reproduction and reproductive organ cancers. Reproduction 2016, 152, R167-R178, doi:10.1530/REP-16-0031.

55. Fu, B.; Ma, H.; Liu, D. Endogenous retroviruses function as gene expression regulatory elements during mammalian pre-implantation embryo development. Int. J. Mol. Sci. 2019, 20, 790-810, doi:10.3390/ijms20030790.

56. Denner, J. Expression and function of endogenous retroviruses in the placenta. Apmis 2016, 124, 31-43, doi:10.1111/apm.12474.

57. Lokossou, A.G.; Toudic, C.; Nguyen, P.T.; Elisseeff, X.; Vargas, A.; Rassart, É.; Lafond, J.; Leduc, L.; Bourgault, S.; Gilbert, C.; et al. Endogenous retrovirus-encoded Syncytin-2 contributes to exosome-mediated immunosuppression of T cells. Biol. Reprod. 2020, 102, 185-198, doi:10.1093/biolre/ioz124.

58. Blaise, S.; Ruggieri, A.; Dewannieux, M.; Cosset, F.-L.; Heidmann, T. Identification of an Envelope Protein from the FRD Family of Human Endogenous Retroviruses (HERV-FRD) Conferring Infectivity and Functional Conservation among Simians. J. Virol. 2004, 78, 1050-1054, doi:10.1128/jvi.78.2.1050-1054.2004.

59. Badierah, R.A.; Uversky, V.N.; Redwan, E.M. Dancing with Trojan horses: an interplay between the extracellular vesicles and viruses. J. Biomol. Struct. Dyn. 2021, 39, 3034-3060, doi:10.1080/07391102.2020.1756409.

60. Mause, S.F.; Weber, C. Microparticles: Protagonists of a novel communication network for intercellular information exchange. Circ. Res. 2010, 107, 1047-1057.

61. Zaborowski, M.P.; Balaj, L.; Breakefield, X.O.; Lai, C.P. Extracellular Vesicles: Composition, Biological Relevance, and Methods of Study. Bioscience 2015, 65, 783-797.

62. Hoen, E.N.; Cremer, T.; Gallo, R.C.; Margolis, L.B. Extracellular vesicles and viruses: Are they close relatives? Proc. Natl. Acad. Sci. U. S. A. 2016, 113, 9155-9161.

63. Wurdinger, T.; Gatson, N.N.; Balaj, L.; Kaur, B.; Breakefield, X.O.; Pegtel, D.M. Extracellular Vesicles and Their Convergence with Viral Pathways. Adv. Virol. 2012, 2012, 12, doi:10.1155/2012/767694.

64. Meckes, D.G. Exosomal Communication Goes Viral. J. Virol. 2015, 89, 5200-5203, doi:10.1128/jvi.02470-14.

65. Ruiss, R.; Jochum, S.; Mocikat, R.; Hammerschmidt, W.; Zeidler, R. EBV-gp350 confers B-cell tropism to tailored exosomes is a neo-antigen in normal and malignant B cells-a new option for the treatment of B-CLL. PLoS One 
2011, 6, e25294, doi:10.1371/journal.pone.0025294.

66. Zhou, W.; Woodson, M.; Sherman, M.B.; Neelakanta, G.; Sultana, H. Exosomes mediate Zika virus transmission through SMPD3 neutral Sphingomyelinase in cortical neurons. Emerg. Microbes Infect. 2019, 8, 307-326, doi:10.1080/22221751.2019.1578188.

67. Kim, E.J.; Jacobs, M.W.; Ito-Cole, T.; Callaway, E.M. Improved Monosynaptic Neural Circuit Tracing Using Engineered Rabies Virus Glycoproteins. Cell Rep. 2016, 15, 692-699, doi:10.1016/j.celrep.2016.03.067.

68. Zhou, W.; Woodson, M.; Neupane, B.; Bai, F.; Sherman, M.B.; Choi, K.H.; Neelakanta, G.; Sultana, H. Exosomes serve as novel modes of tick-borne flavivirus transmission from arthropod to human cells and facilitates dissemination of viral RNA and proteins to the vertebrate neuronal cells. PLoS Pathog. 2018, 14, e1006764, doi:10.1371/journal.ppat.1006764.

69. Sanjuán, R. Collective Infectious Units in Viruses. Trends Microbiol. 2017, 25, 402-412.

70. Rozmyslowicz, T.; Majka, M.; Kijowski, J.; Murphy, S.L.; Conover, D.O.; Poncz, M.; Ratajczak, J.; Gaulton, G.N.; Ratajczak, M.Z. Platelet- and megakaryocyte-derived microparticles transfer CXCR4 receptor to CXCR4-null cells and make them susceptible to infection by X4-HIV. Aids 2003, 17, 33-42, doi:10.1097/00002030-20030103000006.

71. Mack, M.; Kleinschmidt, A.; Brühl, H.; Klier, C.; Nelson, P.J.; Cihak, J.; Plachý, J.; Stangassinger, M.; Erfle, V.; Schlöndorff, D. Transfer of the chemokine receptor CCR5 between cells by membrane- derived microparticles: A mechanism for cellular human immunodeficiency virus 1 infection. Nat. Med. 2000, 6, 769-775, doi:10.1038/77498.

72. Feng, Z.; Hensley, L.; McKnight, K.L.; Hu, F.; Madden, V.; Ping, L.; Jeong, S.H.; Walker, C.; Lanford, R.E.; Lemon, S.M. A pathogenic picornavirus acquires an envelope by hijacking cellular membranes. Nature 2013, 496, 367371, doi:10.1038/nature12029.

73. Yao, Z.; Qiao, Y.; Li, X.; Chen, J.; Ding, J.; Bai, L.; Shen, F.; Shi, B.; Liu, J.; Peng, L.; et al. Exosomes Exploit the Virus Entry Machinery and Pathway To Transmit Alpha Interferon-Induced Antiviral Activity. J. Virol. 2018, 92, e01578-18, doi:10.1128/jvi.01578-18.

74. Yang, Y.; Han, Q.; Hou, Z.; Zhang, C.; Tian, Z.; Zhang, J. Exosomes mediate hepatitis B virus (HBV) transmission and NK-cell dysfunction. Cell. Mol. Immunol. 2017, 14, 465-475, doi:10.1038/cmi.2016.24.

75. Ramakrishnaiah, V.; Thumann, C.; Fofana, I.; Habersetzer, F.; Pan, Q.; De Ruiter, P.E.; Willemsen, R.; Demmers, J.A.A.; Raj, V.S.; Jenster, G.; et al. Exosome-mediated transmission of hepatitis C virus between human hepatoma Huh7.5 cells. Proc. Natl. Acad. Sci. U. S. A. 2013, 110, 13109-13113, doi:10.1073/pnas.1221899110.

76. Yang, J.E.; Rossignol, E.D.; Chang, D.; Zaia, J.; Forrester, I.; Raja, K.; Winbigler, H.; Nicastro, D.; Jackson, W.T.; Bullitt, E. Complexity and ultrastructure of infectious extracellular vesicles from cells infected by non-enveloped virus. Sci. Rep. 2020, 10, 7939, doi:10.1038/s41598-020-64531-1.

77. Izquierdo-Useros, N.; Naranjo-Gómez, M.; Archer, J.; Hatch, S.C.; Erkizia, I.; Blanco, J.; Borràs, F.E.; Puertas, M.C.; Connor, J.H.; Fernádez-Figueras, M.T.; et al. Capture and transfer of HIV-1 particles by mature dendritic 
cells converges with the exosome-dissemination pathway. Blood 2009, 113, 2732-2741, doi:10.1182/blood-200805-158642.

78. Kadiu, I.; Narayanasamy, P.; Dash, P.K.; Zhang, W.; Gendelman, H.E. Biochemical and Biologic Characterization of Exosomes and Microvesicles as Facilitators of HIV-1 Infection in Macrophages. J. Immunol. 2012, 189, 744-754, doi:10.4049/jimmunol.1102244.

79. Narayanan, A.; Iordanskiy, S.; Das, R.; Van Duyne, R.; Santos, S.; Jaworski, E.; Guendel, I.; Sampey, G.; Dalby, E.; Iglesias-Ussel, M.; et al. Exosomes derived from HIV-1-infected cells contain trans-activation response element RNA. J. Biol. Chem. 2013, 288, 20014-20033, doi:10.1074/jbc.M112.438895.

80. Fang, Y.; Wu, N.; Gan, X.; Yan, W.; Morrell, J.C.; Gould, S.J. Higher-order oligomerization targets plasma membrane proteins and HIV Gag to exosomes. PLoS Biol. 2007, 5, 1267-1283, doi:10.1371/journal.pbio.0050158.

81. Lee, J.H.; Schierer, S.; Blume, K.; Dindorf, J.; Wittki, S.; Xiang, W.; Ostalecki, C.; Koliha, N.; Wild, S.; Schuler, G.; et al. HIV-Nef and ADAM17-Containing Plasma Extracellular Vesicles Induce and Correlate with Immune Pathogenesis in Chronic HIV Infection. EBioMedicine 2016, 6, 103-113, doi:10.1016/j.ebiom.2016.03.004.

82. Raymond, A.D.; Campbell-Sims, T.C.; Khan, M.; Lang, M.; Huang, M.B.; Bond, V.C.; Powell, M.D. HIV type 1 Nef is released from infected cells in CD45+ microvesicles and is present in the plasma of HIV-infected individuals. AIDS Res. Hum. Retroviruses 2011, 27, 167-178, doi:10.1089/aid.2009.0170.

83. Reyes-Ruiz, J.M.; Osuna-Ramos, J.F.; De Jesús-González, L.A.; Hurtado-Monzón, A.M.; Farfan-Morales, C.N.; Cervantes-Salazar, M.; Bolaños, J.; Cigarroa-Mayorga, O.E.; Martín-Martínez, E.S.; Medina, F.; et al. Isolation and characterization of exosomes released from mosquito cells infected with dengue virus. Virus Res. 2019, 266, 1-14, doi:10.1016/j.virusres.2019.03.015.

84. Vora, A.; Zhou, W.; Londono-Renteria, B.; Woodson, M.; Sherman, M.B.; Colpitts, T.M.; Neelakanta, G.; Sultana, H. Arthropod EVs mediate dengue virus transmission through interaction with a tetraspanin domain containing glycoprotein Tsp29Fb. Proc. Natl. Acad. Sci. U. S. A. 2018, 115, E6604-E6613, doi:10.1073/pnas.1720125115.

85. Pleet, M.L.; DeMarino, C.; Stonier, S.W.; Dye, J.M.; Jacobson, S.; Aman, M.J.; Kashanchi, F. Extracellular vesicles and ebola virus: A new mechanism of immune evasion. Viruses 2019, 11, 410-419.

86. Chahar, H.S.; Corsello, T.; Kudlicki, A.S.; Komaravelli, N.; Casola, A. Respiratory Syncytial Virus Infection Changes Cargo Composition of Exosome Released from Airway Epithelial Cells. Sci. Rep. 2018, 8, 387-401, doi:10.1038/s41598-017-18672-5.

87. Sadeghipour, S.; Mathias, R.A. Herpesviruses hijack host exosomes for viral pathogenesis. Semin. Cell Dev. Biol. 2017, 67, 91-100.

88. Teow, S.Y.; Liew, K.; Khoo, A.S.B.; Peh, S.C. Pathogenic role of exosomes in epstein-barr virus (EBV)-associated cancers. Int. J. Biol. Sci. 2017, 13, 1276-1286.

89. Zhao, M.; Nanbo, A.; Sun, L.; Lin, Z. Extracellular vesicles in epstein-barr virus' life cycle and pathogenesis. Microorganisms 2019, 7, 48-59, doi:10.3390/microorganisms7020048. 
90. Votteler, J.; Sundquist, W.I. Virus budding and the ESCRT pathway. Cell Host Microbe 2013, 14, 232-241, doi:10.1016/j.chom.2013.08.012.

91. Demirov, D.G.; Ono, A.; Orenstein, J.M.; Freed, E.O. Overexpression of the N-terminal domain of TSG101 inhibits HIV-1 budding by blocking late domain function. Proc. Natl. Acad. Sci. U. S. A. 2002, 99, 955-960, doi:10.1073/pnas.032511899.

92. Martin-Serrano, J.; Zang, T.; Bieniasz, P.D. Role of ESCRT-I in Retroviral Budding. J. Virol. 2003, 77, 4794-4804, doi:10.1128/jvi.77.8.4794-4804.2003.

93. VerPlank, L.; Bouamr, F.; LaGrassa, T.J.; Agresta, B.; Kikonyogo, A.; Leis, J.; Carter, C.A. Tsg101, a homologue of ubiquitin-conjugating (E2) enzymes, binds the L domain in HIV type 1 Pr55Gag. Proc. Natl. Acad. Sci. U. S. A. 2001, 98, 7724-7729, doi:10.1073/pnas.131059198.

94. Villarroya-Beltri, C.; Baixauli, F.; Mittelbrunn, M.; Fernández-Delgado, I.; Torralba, D.; Moreno-Gonzalo, O.; Baldanta, S.; Enrich, C.; Guerra, S.; Sánchez-Madrid, F. ISGylation controls exosome secretion by promoting lysosomal degradation of MVB proteins. Nat. Commun. 2016, 7, 13588, doi:10.1038/ncomms13588.

95. Di Bonito, P.; Ridolfi, B.; Columba-Cabezas, S.; Giovannelli, A.; Chiozzini, C.; Manfredi, F.; Anticoli, S.; Arenaccio, C.; Federico, M. HPV-E7 delivered by engineered exosomes elicits a protective CD8+ T cell-mediated immune response. Viruses 2015, 7, 1079-1099, doi:10.3390/v7031079.

96. Manfredi, F.; Di Bonito, P.; Arenaccio, C.; Anticoli, S.; Federico, M. Incorporation of heterologous proteins in engineered exosomes. In Methods in Molecular Biology; 2016; Vol. 1448, pp. 249-260.

97. McNamara, R.P.; Costantini, L.M.; Myers, T.A.; Schouest, B.; Maness, N.J.; Griffith, J.D.; Damania, B.A.; Maclean, A.G.; Dittmer, D.P. Nef secretion into extracellular vesicles or exosomes is conserved across human and simian immunodeficiency viruses. MBio 2018, 9, e02344-17, doi:10.1128/mBio.02344-17.

98. Anticoli, S.; Manfredi, F.; Chiozzini, C.; Arenaccio, C.; Olivetta, E.; Ferrantelli, F.; Capocefalo, A.; Falcone, E.; Ruggieri, A.; Federico, M. An Exosome-Based Vaccine Platform Imparts Cytotoxic T Lymphocyte Immunity Against Viral Antigens. Biotechnol. J. 2018, 13, e1700443, doi:10.1002/biot.201700443.

99. Srivastava, A. In vivo tissue-tropism of adeno-associated viral vectors. Curr. Opin. Virol. 2016, 21, 75-80, doi:10.1016/j.coviro.2016.08.003.

100. Ayora-Talavera, G. Sialic acid receptors: focus on their role in influenza infection. J. Receptor. Ligand Channel Res. 2018, 10, 1-11, doi:10.2147/JRLCR.S140624.

101. Kubota, M.; Matsuoka, R.; Suzuki, T.; Yonekura, K.; Yanagi, Y.; Hashiguchi, T. Molecular Mechanism of the Flexible Glycan Receptor Recognition by Mumps Virus. J. Virol. 2019, 93, e00344-19, doi:10.1128/jvi.00344-19.

102. Marcink, T.C.; Wang, T.; Georges, A. des; Porotto, M.; Moscona, A. Human parainfluenza virus fusion complex glycoproteins imaged in action on authentic viral surfaces. PLoS Pathog. 2020, 16, e1008883, doi:10.1371/journal.ppat.1008883.

103. Pearce, O.M.T.; Läubli, H. Sialic acids in cancer biology and immunity. Glycobiology 2016, 26, 111-128, 


\section{doi:10.1093/GLYCOB/CWV097.}

104. Li, W. The Hepatitis B Virus Receptor. Annu. Rev. Cell Dev. Biol. 2015, 31, 125-147, doi:10.1146/annurev-cellbio100814-125241.

105. Salhab, A.; Amer, J.; Lu, Y.; Safadi, R. Sodium+/taurocholate cotransporting polypeptide as target therapy for liver fibrosis. Gut 2021, 2020, 323345, doi:10.1136/gutjnl-2020-323345.

106. Cocquerel, L.; Voisset, C.; Dubuisson, J. Hepatitis C virus entry: Potential receptors and their biological functions. J. Gen. Virol. 2006, 87, 1075-1084, doi:10.1099/vir.0.81646-0.

107. Zhang, Y.; Qian, H.; Xu, A.; Yang, G. Increased expression of CD81 is associated with poor prognosis of prostate cancer and increases the progression of prostate cancer cells invitro. Exp. Ther. Med. 2019, 19, 755-761, doi:10.3892/etm.2019.8244.

108. Feng, H.; Wang, M.; Wu, C.; Yu, J.; Wang, D.; Ma, J.; Han, J. High scavenger receptor class B type i expression is related to tumor aggressiveness and poor prognosis in lung adenocarcinoma. Med. (United States) 2018, 97, e0203, doi:10.1097/MD.0000000000010203.

109. Bates, P.; Young, J.A.T.; Varmus, H.E. A receptor for subgroup A Rous sarcoma virus is related to the low density lipoprotein receptor. Cell 1993, 74, 1043-1051, doi:10.1016/0092-8674(93)90726-7.

110. Finkelshtein, D.; Werman, A.; Novick, D.; Barak, S.; Rubinstein, M. LDL receptor and its family members serve as the cellular receptors for vesicular stomatitis virus. Proc. Natl. Acad. Sci. U. S. A. 2013, 110, 7306-7311, doi:10.1073/pnas.1214441110.

111. Migita, T.; Ruiz, S.; Fornari, A.; Fiorentino, M.; Priolo, C.; Zadra, G.; Inazuka, F.; Grisanzio, C.; Palescandolo, E.; Shin, E.; et al. Fatty Acid Synthase: A Metabolic Enzyme and Candidate Oncogene in Prostate Cancer. JNCI J. Natl. Cancer Inst. 2009, 101, 519-532, doi:10.1093/JNCI/DJP030.

112. Gallagher, E.J.; Zelenko, Z.; Neel, B.A.; Antoniou, I.M.; Rajan, L.; Kase, N.; LeRoith, D. Elevated tumor LDLR expression accelerates LDL cholesterol-mediated breast cancer growth in mouse models of hyperlipidemia. Oncogene 20173646 2017, 36, 6462-6471, doi:10.1038/onc.2017.247.

113. Yoon, V.; Fridkis-Hareli, M.; Munisamy, S.; Lee, J.; Anastasiades, D.; Stevceva, L. The GP120 Molecule of HIV-1 and its Interaction with T Cells. Curr. Med. Chem. 2010, 17, 741-749, doi:10.2174/092986710790514499.

114. Hussaini, M.O.; Kreisel, F.H.; Hassan, A.; Nguyen, T.T.; Frater, J.L. CD4-positive diffuse large B-cell lymphoma: A variant with aggressive clinical potential. World J. Methodol. 2016, 6, 181, doi:10.5662/wjm.v6.i3.181.

115. Anderson, C.S.; Chu, C.Y.; Wang, Q.; Mereness, J.A.; Ren, Y.; Donlon, K.; Bhattacharya, S.; Misra, R.S.; Walsh, E.E.; Pryhuber, G.S.; et al. CX3CR1 as a respiratory syncytial virus receptor in pediatric human lung. Pediatr. Res. 2020, 87, 862-867, doi:10.1038/s41390-019-0677-0.

116. Griffiths, C.D.; Bilawchuk, L.M.; McDonough, J.E.; Jamieson, K.C.; Elawar, F.; Cen, Y.; Duan, W.; Lin, C.; Song, H.; Casanova, J.L.; et al. IGF1R is an entry receptor for respiratory syncytial virus. Nature 2020, 583, 615-619, doi:10.1038/s41586-020-2369-7. 
117. Yuan, J.; Yin, Z.; Tao, K.; Wang, G.; Gao, J. Function of insulin-like growth factor 1 receptor in cancer resistance to chemotherapy (Review). Oncol. Lett. 2018, 15, 41-47, doi:10.3892/OL.2017.7276.

118. Gonçalves, D.U.; Proietti, F.A.; Ribas, J.G.R.; Araújo, M.G.; Pinheiro, S.R.; Guedes, A.C.; Carneiro-Proietti, A.B.F. Epidemiology, treatment, and prevention of human T-cell leukemia virus type 1-associated diseases. Clin. Microbiol. Rev. 2010, 23, 577-589, doi:10.1128/CMR.00063-09.

119. KC, C.; IW, C.; RM, R.; FR, A.; MM, C.; MD, B.; RS, V.; GR, P.; RG, A.; FA, S. GLUT1 expression in malignant tumors and its use as an immunodiagnostic marker. Clinics (Sao Paulo). 2011, 66, 965-972, doi:10.1590/S180759322011000600008 .

120. Tatsuo, H.; Yanagi, Y. The morbillivirus receptor SLAM (CD150). Microbiol. Immunol. 2002, 46, 135-142, doi:10.1111/j.1348-0421.2002.tb02678.x.

121. Romanets-Korbut, O.; Najakshin, A.M.; Yurchenko, M.; Malysheva, T.A.; Kovalevska, L.; Shlapatska, L.M.; Zozulya, Y.A.; Taranin, A. V.; Horvat, B.; Sidorenko, S.P. Expression of CD150 in tumors of the central nervous system: Identification of a novel isoform. PLoS One 2015, 10, e0118302, doi:10.1371/journal.pone.0118302.

122. Bonaparte, M.I.; Dimitrov, A.S.; Bossart, K.N.; Crameri, G.; Mungall, B.A.; Bishop, K.A.; Choudhry, V.; Dimitrov, D.S.; Wang, L.-F.; Eaton, B.T.; et al. Ephrin-B2 ligand is a functional receptor for Hendra virus and Nipah virus. Proc. Natl. Acad. Sci. 2005, 102, 10652-10657, doi:10.1073/PNAS.0504887102.

123. Alam, S.M.; Fujimoto, J.; Jahan, I.; Sato, E.; Tamaya, T. Overexpression of ephrinB2 and EphB4 in tumor advancement of uterine endometrial cancers. Ann. Oncol. 2007, 18, 485-490, doi:10.1093/annonc/mdl414.

124. Jia, H.P.; Look, D.C.; Shi, L.; Hickey, M.; Pewe, L.; Netland, J.; Farzan, M.; Wohlford-Lenane, C.; Perlman, S.; McCray, P.B. ACE2 Receptor Expression and Severe Acute Respiratory Syndrome Coronavirus Infection Depend on Differentiation of Human Airway Epithelia. J. Virol. 2005, 79, 14614-14621, doi:10.1128/jvi.79.23.14614-14621.2005.

125. Errarte, P.; Beitia, M.; Perez, I.; Manterola, L.; Lawrie, C.H.; Solano-Iturri, J.D.; Calvete-Candenas, J.; Unda, M.; López, J.I.; Larrinaga, G. Expression and activity of angiotensin-regulating enzymes is associated with prognostic outcome in clear cell renal cell carcinoma patients. PLoS One 2017, 12, e0181711, doi:10.1371/JOURNAL.PONE.0181711.

126. Kuhn, J.H.; Radoshitzky, S.R.; Guth, A.C.; Warfield, K.L.; Li, W.; Vincent, M.J.; Towner, J.S.; Nichol, S.T.; Bavari, S.; Choe, H.; et al. Conserved receptor-binding domains of Lake Victoria marburgvirus and Zaire ebolavirus bind a common receptor. J. Biol. Chem. 2006, 281, 15951-15958, doi:10.1074/jbc.M601796200.

127. Zheng, X.; Xu, K.; Chen, L.; Zhou, Y.; Jiang, J. Prognostic value of TIM-1 expression in human non-small-cell lung cancer. J. Transl. Med. 2019171 2019, 17, 1-12, doi:10.1186/S12967-019-1931-2.

128. Cao, W.; Henry, M.D.; Borrow, P.; Yamada, H.; Elder, J.H.; Ravkov, E. V.; Nichol, S.T.; Compans, R.W.; Campbell, K.P.; Oldstone, M.B.A. Identification of $\alpha$-dystroglycan as a receptor for lymphocytic choriomeningitis virus and Lassa fever virus. Science (80-. ). 1998, 282, 2079-2081, doi:10.1126/science.282.5396.2079.

129. Kunz, S.; Rojek, J.M.; Perez, M.; Spiropoulou, C.F.; Oldstone, M.B.A. Characterization of the Interaction of Lassa 
Fever Virus with Its Cellular Receptor $\alpha$-Dystroglycan. J. Virol. 2005, 79, 5979-5987, doi:10.1128/jvi.79.10.59795987.2005.

130. Sciandra, F.; Bigotti, M.G.; Giardina, B.; Bozzi, M.; Brancaccio, A. Genetic Engineering of Dystroglycan in Animal Models of Muscular Dystrophy. Biomed Res. Int. 2015, 2015, 635792, doi:10.1155/2015/635792.

131. Cohen-Dvashi, H.; Kilimnik, I.; Diskin, R. Structural basis for receptor recognition by Lujo virus. Nat. Microbiol. 2018, 3, 1153-1160, doi:10.1038/s41564-018-0224-5.

132. Yasuoka, H.; Kodama, R.; Tsujimoto, M.; Yoshidome, K.; Akamatsu, H.; Nakahara, M.; Inagaki, M.; Sanke, T.; Nakamura, Y. Neuropilin-2 expression in breast cancer: correlation with lymph node metastasis, poor prognosis, and regulation of CXCR4 expression. BMC Cancer 200991 2009, 9, 1-7, doi:10.1186/1471-2407-9-220.

133. Cong, H.; Jiang, Y.; Tien, P. Identification of the Myelin Oligodendrocyte Glycoprotein as a Cellular Receptor for Rubella Virus. J. Virol. 2011, 85, 11038-11047, doi:10.1128/jvi.05398-11.

134. Shu, Y.; Long, Y.; Wang, S.; Hu, W.; Zhou, J.; Xu, H.; Chen, C.; Ou, Y.; Lu, Z.; Lau, A.Y.; et al. Brain histopathological study and prognosis in MOG antibody-associated demyelinating pseudotumor. Ann. Clin. Transl. Neurol. 2019, 6, 392-396, doi:10.1002/acn3.712.

135. Zhou, D.; Srivastava, R.; Nessler, S.; Grummel, V.; Sommer, N.; Brück, W.; Hartung, H.P.; Stadelmann, C.; Hemmer, B. Identification of a pathogenic antibody response to native myelin oligodendrocyte glycoprotein in multiple sclerosis. Proc. Natl. Acad. Sci. U. S. A. 2006, 103, 19057-19062, doi:10.1073/pnas.0607242103.

136. Ma, H.; Kim, A.S.; Kafai, N.M.; Earnest, J.T.; Shah, A.P.; Case, J.B.; Basore, K.; Gilliland, T.C.; Sun, C.; Nelson, C.A.; et al. LDLRAD3 is a receptor for Venezuelan equine encephalitis virus. Nature 2020, 588, 308-314, doi:10.1038/s41586-020-2915-3.

137. Campion, O.; Al Khalifa, T.; Langlois, B.; Thevenard-Devy, J.; Salesse, S.; Savary, K.; Schneider, C.; Etique, N.; Dedieu, S.; Devy, J. Contribution of the Low-Density Lipoprotein Receptor Family to Breast Cancer Progression. Front. Oncol. 2020, 10, 882, doi:10.3389/fonc.2020.00882.

138. Lo, Y.-L.; Liou, G.-G.; Lyu, J.-H.; Hsiao, M.; Hsu, T.-L.; Wong, C.-H. Dengue Virus Infection Is through a Cooperative Interaction between a Mannose Receptor and CLEC5A on Macrophage as a Multivalent HeteroComplex. PLoS One 2016, 11, e0166474, doi:10.1371/JOURNAL.PONE.0166474.

139. Colpitts, T.M.; Conway, M.J.; Montgomery, R.R.; Fikrig, E. West Nile virus: Biology, transmission, and human infection. Clin. Microbiol. Rev. 2012, 25, 635-648, doi:10.1128/CMR.00045-12.

140. Liu, D.R.; Guan, Q.L.; Gao, M.T.; Jiang, L.; Kang, H.X. Mannose receptor as a potential biomarker for gastric cancer: A pilot study. Int. J. Biol. Markers 2017, 32, e278-e283, doi:10.5301/jbm.5000244.

141. Mukherjee, S.; Sengupta, N.; Chaudhuri, A.; Akbar, I.; Singh, N.; Chakraborty, S.; Suryawanshi, A.R.; Bhattacharyya, A.; Basu, A. PLVAP and GKN3 Are Two Critical Host Cell Receptors Which Facilitate Japanese Encephalitis Virus Entry Into Neurons. Sci. Rep. 2018, 8, 1-16, doi:10.1038/s41598-018-30054-z.

142. Guo, L.; Zhang, H.; Hou, Y.; Wei, T.; Liu, J. Plasmalemma vesicle-associated protein: A crucial component of 
vascular homeostasis (Review). Exp. Ther. Med. 2016, 12, 1639-1644, doi:10.3892/ETM.2016.3557.

143. Chen, X.; Chen, J.; Yang, M. Glucagon-like peptide-2 receptor is a receptor for tick-borne encephalitis virus to infect nerve cells. 2021, 1-13, doi:10.21203/RS.3.RS-127347/V1.

144. Orhan, A.; Gögenur, I.; Kissow, H. The intestinotrophic effects of glucagon-like peptide-2 in relation to intestinal neoplasia. J. Clin. Endocrinol. Metab. 2018, 103, 2827-2837, doi:10.1210/jc.2018-00655.

145. Wang, J.; Wang, Z.; Liu, R.; Shuai, L.; Wang, X.; Luo, J.; Wang, C.; Chen, W.; Wang, X.; Ge, J.; et al. Metabotropic glutamate receptor subtype 2 is a cellular receptor for rabies virus. PLoS Pathog. 2018, 14, e1007189, doi:10.1371/journal.ppat.1007189.

146. Aleman, M.; Milbank, A.; Harsch, K.M.; Detore, N.; Klein, E.; Heston, W. Expression of metabotropic glutamate receptors in human prostate cancers and its potential signaling through prostate specific membrane antigen. Cancer Res. 2004, 64.

147. A, A.; G, C.; G, B.; M, D.; F, S.; RT, N.; V, B.; P, C.; F, G.; F, N. Pharmacological blockade of group II metabotropic glutamate receptors reduces the growth of glioma cells in vivo. Neuro. Oncol. 2005, 7, 236-245, doi:10.1215/S1152851704000961.

148. Yan, Y.; Vasudevan, S.; Nguyen, H.; Merlin, D. Intestinal Epithelial CD98: An Oligomeric and Multifunctional Protein. Biochim. Biophys. Acta 2008, 1780, 1087, doi:10.1016/J.BBAGEN.2008.06.007.

149. Cantor, J.M.; Ginsberg, M.H. CD98 at the crossroads of adaptive immunity and cancer. J. Cell Sci. 2012, 125, 13731382, doi:10.1242/jcs.096040.

150. Spear, P.G. Herpes simplex virus: Receptors and ligands for cell entry. Cell. Microbiol. 2004, 6, 401-410, doi:10.1111/j.1462-5822.2004.00389.x.

151. Vicente, C.M.; da Silva, D.A.; Sartorio, P.V.; Silva, T.D.; Saad, S.S.; Nader, H.B.; Forones, N.M.; Toma, L. Heparan sulfate proteoglycans in human colorectal cancer. Anal. Cell. Pathol. 2018, 2018, doi:10.1155/2018/8389595.

152. Ross, S.R.; Schofield, J.J.; Farr, C.J.; Bucan, M. Mouse transferrin receptor 1 is the cell entry receptor for mouse mammary tumor virus. Proc. Natl. Acad. Sci. U. S. A. 2002, 99, 12386-12390, doi:10.1073/pnas.192360099.

153. Shen, Y.; Li, X.; Dong, D.; Zhang, B.; Xue, Y.; Shang, P. Transferrin receptor 1 in cancer: a new sight for cancer therapy. Am. J. Cancer Res. 2018, 8, 916.

154. Esnault, C.; Priet, S.; Ribet, D.; Vernochet, C.; Bruls, T.; Lavialle, C.; Weissenbach, J.; Heidmann, T. A placentaspecific receptor for the fusogenic, endogenous retrovirus-derived, human syncytin-2. Proc. Natl. Acad. Sci. U. S. A. 2008, 105, 17532-17537, doi:10.1073/pnas.0807413105.

155. Toda, K.; Nishikawa, G.; Iwamoto, M.; Itatani, Y.; Takahashi, R.; Sakai, Y.; Kawada, K. Clinical role of ASCT2 (SLC1A5) in KRAS-mutated colorectal cancer. Int. J. Mol. Sci. 2017, 18, 1632, doi:10.3390/ijms18081632.

156. Zhang, W.; Jiang, X.; Bao, J.; Wang, Y.; Liu, H.; Tang, L. Exosomes in pathogen infections: A bridge to deliver molecules and link functions. Front. Immunol. 2018, 9, 90, doi:10.3389/fimmu.2018.00090. 
157. Kim, G.B.; Nam, G.H.; Hong, Y.; Woo, J.; Cho, Y.; Kwon, I.C.; Yang, Y.; Kim, I.S. Xenogenization of tumor cells by fusogenic exosomes in tumor microenvironment ignites and propagates antitumor immunity. Sci. Adv. 2020, 6, doi:10.1126/sciadv.aaz2083.

158. Kima, I.S.; Jenni, S.; Stanifer, M.L.; Roth, E.; Whelan, S.P.J.; Van Oijen, A.M.; Harrison, S.C. Mechanism of membrane fusion induced by vesicular stomatitis virus G protein. Proc. Natl. Acad. Sci. U. S. A. 2017, 114, E28E36, doi:10.1073/pnas.1618883114.

159. Meyer, C.; Losacco, J.; Stickney, Z.; Li, L.; Marriott, G.; Lu, B. Pseudotyping exosomes for enhanced protein delivery in mammalian cells. Int. J. Nanomedicine 2017, 12, 3153-3170, doi:10.2147/IJN.S133430.

160. Yang, Y.; Hong, Y.; Nam, G.H.; Chung, J.H.; Koh, E.; Kim, I.S. Virus-Mimetic Fusogenic Exosomes for Direct Delivery of Integral Membrane Proteins to Target Cell Membranes. Adv. Mater. 2017, 29, 1605604, doi:10.1002/adma.201605604.

161. Masciopinto, F.; Giovani, C.; Campagnoli, S.; Galli-Stampino, L.; Colombatto, P.; Brunetto, M.; Yen, T.S.B.; Houghton, M.; Pileri, P.; Abrignani, S. Association of hepatitis $C$ virus envelope proteins with exosomes. Eur. J. Immunol. 2004, 34, 2834-2842, doi:10.1002/eji.200424887.

162. Vallhov, H.; Gutzeit, C.; Johansson, S.M.; Nagy, N.; Paul, M.; Li, Q.; Friend, S.; George, T.C.; Klein, E.; Scheynius, A.; et al. Exosomes Containing Glycoprotein 350 Released by EBV-Transformed B Cells Selectively Target B Cells through CD21 and Block EBV Infection In Vitro. J. Immunol. 2011, 186, 73-82, doi:10.4049/jimmunol.1001145.

163. Alvarez-Erviti, L.; Seow, Y.; Yin, H.; Betts, C.; Lakhal, S.; Wood, M.J.A. Delivery of siRNA to the mouse brain by systemic injection of targeted exosomes. Nat. Biotechnol. 2011, 29, 341-345, doi:10.1038/nbt.1807.

164. Fu, Y.; Xiong, S. Tagged extracellular vesicles with the RBD of the viral spike protein for delivery of antiviral agents against SARS-COV-2 infection. J. Control. Release 2021, 335, 584-595, doi:10.1016/j.jconrel.2021.05.049.

165. Salomon, C.; Nuzhat, Z.; Dixon, C.L.; Menon, R. Placental Exosomes During Gestation: Liquid Biopsies Carrying Signals for the Regulation of Human Parturition. Curr. Pharm. Des. 2018, 24, 974-982, doi:10.2174/1381612824666180125164429.

166. Yue, B.; Yang, H.; Wang, J.; Ru, W.; Wu, J.; Huang, Y.; Lan, X.; Lei, C.; Chen, H. Exosome biogenesis, secretion and function of exosomal miRNAs in skeletal muscle myogenesis. Cell Prolif. 2020, 53, e12857.

167. Hoshino, A.; Costa-Silva, B.; Shen, T.-L.; Rodrigues, G.; Hashimoto, A.; Tesic Mark, M.; Molina, H.; Kohsaka, S.; Di Giannatale, A.; Ceder, S.; et al. Tumour exosome integrins determine organotropic metastasis. Nat. 2015 5277578 2015, 527, 329-335, doi:10.1038/nature15756.

168. I, W.; S, D.; CM, K.; D, L. Exosome-Mediated Metastasis: Communication from a Distance. Dev. Cell 2019, 49, 347-360, doi:10.1016/J.DEVCEL.2019.04.011.

169. Eckwahl, M.J.; Telesnitsky, A.; Wolin, S.L. Host RNA packaging by retroviruses: A newly synthesized story. MBio 2016, 7, doi:10.1128/mBio.02025-15.

170. Chen, Q.; Li, Y.; Liu, Y.; Xu, W.; Zhu, X. Exosomal Non-coding RNAs-Mediated Crosstalk in the Tumor 
Microenvironment. Front. Cell Dev. Biol. 2021, 9, doi:10.3389/fcell.2021.646864.

171. van Eijndhoven, M.A.J.; Baglio, S.R.; Pegtel, D.M. Packaging RNA drugs into extracellular vesicles. Nat. Biomed. Eng. 2020, 4, 6-8, doi:10.1038/s41551-019-0514-0.

172. Villarroya-Beltri, C.; Gutiérrez-Vázquez, C.; Sánchez-Cabo, F.; Pérez-Hernández, D.; Vázquez, J.; MartinCofreces, N.; Martinez-Herrera, D.J.; Pascual-Montano, A.; Mittelbrunn, M.; Sánchez-Madrid, F. Sumoylated hnRNPA2B1 controls the sorting of miRNAs into exosomes through binding to specific motifs. Nat. Commun. 2013, 4, 2980, doi:10.1038/ncomms3980.

173. McKenzie, A.J.; Hoshino, D.; Hong, N.H.; Cha, D.J.; Franklin, J.L.; Coffey, R.J.; Patton, J.G.; Weaver, A.M. KRASMEK Signaling Controls Ago2 Sorting into Exosomes. Cell Rep. 2016, 15, 978-987, doi:10.1016/j.celrep.2016.03.085.

174. Iavello, A.; Frech, V.S.L.; Gai, C.; Deregibus, M.C.; Quesenberry, P.J.; Camussi, G. Role of Alix in miRNA packaging during extracellular vesicle biogenesis. Int. J. Mol. Med. 2016, 37, 958-966, doi:10.3892/ijmm.2016.2488.

175. Hagiwara, K.; Katsuda, T.; Gailhouste, L.; Kosaka, N.; Ochiya, T. Commitment of Annexin A2 in recruitment of microRNAs into extracellular vesicles. FEBS Lett. 2015, 589, 4071-4078, doi:10.1016/j.febslet.2015.11.036.

176. Statello, L.; Maugeri, M.; Garre, E.; Nawaz, M.; Wahlgren, J.; Papadimitriou, A.; Lundqvist, C.; Lindfors, L.; Collén, A.; Sunnerhagen, P.; et al. Identification of RNA-binding proteins in exosomes capable of interacting with different types of RNA: RBP-facilitated transport of RNAs into exosomes. PLoS One 2018, 13, e0195969, doi:10.1371/journal.pone.0195969.

177. Mukherjee, K.; Ghoshal, B.; Ghosh, S.; Chakrabarty, Y.; Shwetha, S.; Das, S.; Bhattacharyya, S.N. Reversible HuR-micro RNA binding controls extracellular export of miR-122 and augments stress response. EMBO Rep. 2016, 17, 1184-1203, doi:10.15252/embr.201541930.

178. Wozniak, A.L.; Adams, A.; King, K.E.; Dunn, W.; Christenson, L.K.; Hung, W.T.; Weinman, S.A. The RNA binding protein FMR1 controls selective exosomal miRNA cargo loading during inflammation. J. Cell Biol. 2020, 219, e201912074, doi:10.1083/JCB.201912074.

179. Zietzer, A.; Hosen, M.R.; Wang, H.; Goody, P.R.; Sylvester, M.; Latz, E.; Nickenig, G.; Werner, N.; Jansen, F. The RNA-binding protein hnRNPU regulates the sorting of microRNA-30c-5p into large extracellular vesicles. J. Extracell. Vesicles 2020, 9, 1786967, doi:10.1080/20013078.2020.1786967.

180. Fabbiano, F.; Corsi, J.; Gurrieri, E.; Trevisan, C.; Notarangelo, M.; D'Agostino, V.G. RNA packaging into extracellular vesicles: An orchestra of RNA-binding proteins? J. Extracell. Vesicles 2020, 10, doi:10.1002/jev2.12043.

181. Stoltzfus, C.M. Synthesis and Processing of Avian Sarcoma Retrovirus RNA. Adv. Virus Res. 1988, 35, 1-38, doi:10.1016/S0065-3527(08)60707-1.

182. Kuzembayeva, M.; Dilley, K.; Sardo, L.; Hu, W.S. Life of psi: How full-length HIV-1 RNAs become packaged genomes in the viral particles. Virology 2014, 454-455, 362-370, doi:10.1016/J.VIROL.2014.01.019.

183. Lu, K.; Heng, X.; Summers, M.F. Structural Determinants and Mechanism of HIV-1 Genome Packaging. J. Mol. Biol. 2011, 410, 609-633, doi:10.1016/J.JMB.2011.04.029. 
184. Aldovini, A.; Young, R.A. Mutations of RNA and protein sequences involved in human immunodeficiency virus type 1 packaging result in production of noninfectious virus. J. Virol. 1990, 64, 1920-1926, doi:10.1128/JVI.64.5.1920-1926.1990.

185. Clever, J.; Sassetti, C.; Parslow, T.G. RNA secondary structure and binding sites for gag gene products in the $5^{\prime}$ packaging signal of human immunodeficiency virus type 1. J. Virol. 1995, 69, 2101-2109, doi:10.1128/JVI.69.4.2101-2109.1995.

186. McBride, M.; MD, S.; Panganiban, A. Efficient encapsidation of human immunodeficiency virus type 1 vectors and further characterization of cis elements required for encapsidation. J. Virol. 1997, 71, 4544-4554, doi:10.1128/JVI.71.6.4544-4554.1997.

187. Heng, X.; S, K.; EL, G.; K, L.; SS, D.; C, L.; K, E.; A, T.; MF, S. Identification of a minimal region of the HIV-1 5'leader required for RNA dimerization, NC binding, and packaging. J. Mol. Biol. 2012, 417, 224-239, doi:10.1016/J.JMB.2012.01.033.

188. Kim, S.H.; Jun, H.J.; Jang, S.I.; You, J.C. The Determination of Importance of Sequences Neighboring the Psi Sequence in Lentiviral Vector Transduction and Packaging Efficiency. PLoS One 2012, 7, e50148, doi:10.1371/JOURNAL.PONE.0050148.

189. Sakuragi, J.; Shioda, T.; Panganiban, A.T. Duplication of the Primary Encapsidation and Dimer Linkage Region of Human Immunodeficiency Virus Type 1 RNA Results in the Appearance of Monomeric RNA in Virions. J. Virol. 2001, 75, 2557-2565, doi:10.1128/JVI.75.6.2557-2565.2001.

190. Mailler, E.; Bernacchi, S.; Marquet, R.; Paillart, J.-C.; Vivet-Boudou, V.; Smyth, R.P. The Life-Cycle of the HIV-1 Gag-RNA Complex. Viruses 2016, Vol. 8, Page 248 2016, 8, 248, doi:10.3390/V8090248.

191. Summers, M.F.; Henderson, L.E.; Chance, M.R.; Bess, J.W.; Jr; South, T.L.; Blake, P.R.; Sagi, I.; Perez-Alvarado, G.; Sowder, R.C.; et al. Nucleocapsid zinc fingers detected in retroviruses: EXAFS studies of intact viruses and the solution-state structure of the nucleocapsid protein from HIV-1. Protein Sci. 1992, 1, 563, doi:10.1002/PRO.5560010502.

192. Cimarelli, A.; Sandin, S.; Höglund, S.; Luban, J. Basic Residues in Human Immunodeficiency Virus Type 1 Nucleocapsid Promote Virion Assembly via Interaction with RNA. J. Virol. 2000, 74, 3046-3057, doi:10.1128/jvi.74.7.3046-3057.2000.

193. Campbell, S.; Rein, A. In vitro assembly properties of human immunodeficiency virus type 1 Gag protein lacking the p6 domain. J. Virol. 1999, 73, 2270-2279, doi:10.1128/JVI.73.3.2270-2279.1999.

194. Nikolaitchik, O.A.; Dilley, K.A.; Fu, W.; Gorelick, R.J.; Tai, S.-H.S.; Soheilian, F.; Ptak, R.G.; Nagashima, K.; Pathak, V.K.; Hu, W.-S. Dimeric RNA Recognition Regulates HIV-1 Genome Packaging. PLOS Pathog. 2013, 9 , e1003249, doi:10.1371/JOURNAL.PPAT.1003249.

195. Miyazaki, Y.; EL, G.; SR, K.; K, I.; K, L.; P, S.; S, S.; A, T.; Summers, M. An RNA structural switch regulates diploid genome packaging by Moloney murine leukemia virus. J. Mol. Biol. 2010, 396, 141-152, doi:10.1016/J.JMB.2009.11.033. 
196. Shen, B.; Wu, N.; Yang, M.; Gould, S.J. Protein targeting to exosomes/microvesicles by plasma membrane anchors. J. Biol. Chem. 2011, doi:10.1074/jbc.M110.208660.

197. Nakagawa, S.; Takahashi, M.U. gEVE: a genome-based endogenous viral element database provides comprehensive viral protein-coding sequences in mammalian genomes. Database (Oxford). 2016, 2016, doi:10.1093/database/baw087.

198. Ashley, J.; Cordy, B.; Lucia, D.; Fradkin, L.G.; Budnik, V.; Thomson, T. Retrovirus-like Gag Protein Arc1 Binds RNA and Traffics across Synaptic Boutons. Cell 2018, doi:10.1016/j.cell.2017.12.022.

199. Abed, M.; Verschueren, E.; Budayeva, H.; Liu, P.; Kirkpatrick, D.S.; Reja, R.; Kummerfeld, S.K.; Webster, J.D.; Gierke, S.; Reichelt, M.; et al. The Gag protein PEG10 binds to RNA and regulates trophoblast stem cell lineage specification. PLoS One 2019, 14, e0214110, doi:10.1371/JOURNAL.PONE.0214110.

200. Segel, M.; Lash, B.; Song, J.; Ladha, A.; Liu, C.C.; Jin, X.; Mekhedov, S.L.; Macrae, R.K.; Koonin, E. V.; Zhang, F. Mammalian retrovirus-like protein PEG10 packages its own mRNA and can be pseudotyped for mRNA delivery. Science (80-. ). 2021, 373, 882-889, doi:10.1126/SCIENCE.ABG6155.

201. Gee, P.; Lung, M.S.Y.; Okuzaki, Y.; Sasakawa, N.; Iguchi, T.; Makita, Y.; Hozumi, H.; Miura, Y.; Yang, L.F.; Iwasaki, M.; et al. Extracellular nanovesicles for packaging of CRISPR-Cas9 protein and sgRNA to induce therapeutic exon skipping. Nat. Commun. 2020, 11, 1-18, doi:10.1038/s41467-020-14957-y.

202. Koppers-Lalic, D.; Hogenboom, M.M.; Middeldorp, J.M.; Pegtel, D.M. Virus-modified exosomes for targeted RNA delivery; A new approach in nanomedicine. Adv. Drug Deliv. Rev. 2013, 65, 348-356. 